Project Management Plan for the Hanford Environmental Dose Reconstruction Project

D. B. Shipler

March 1992
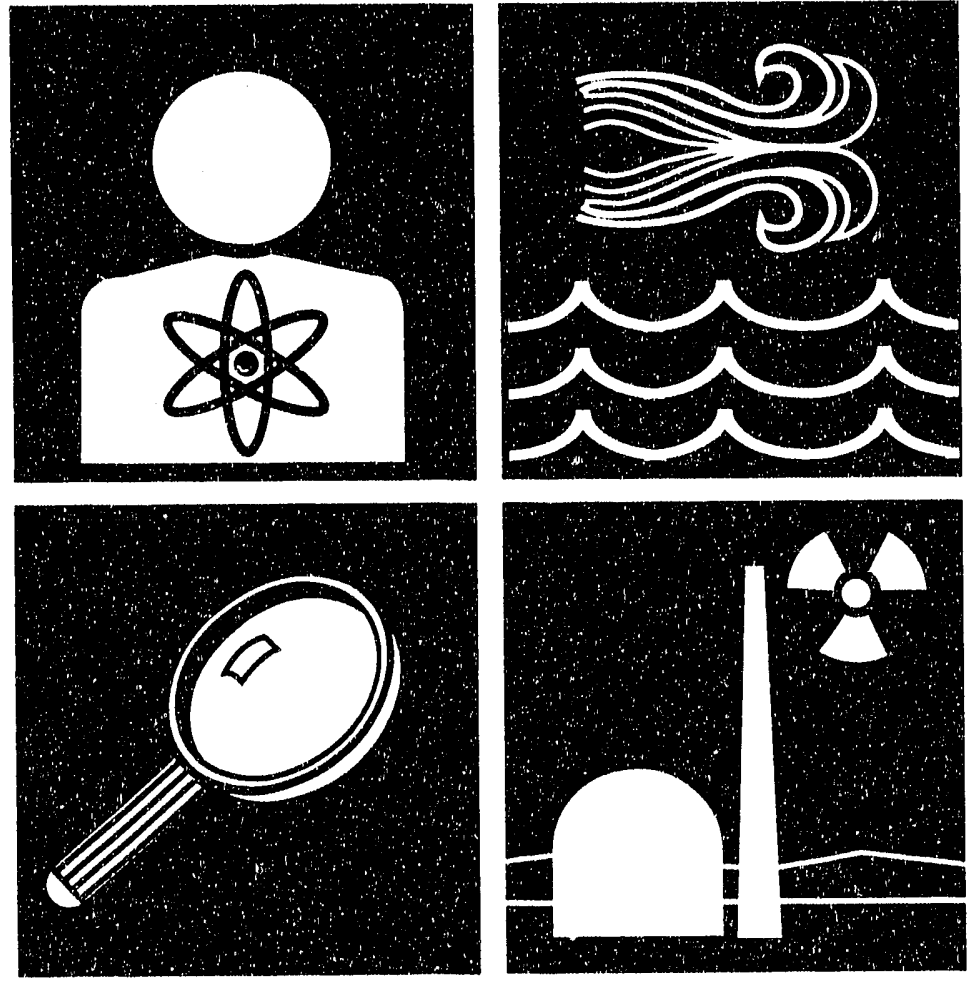

Prepared for the Technical Steering Panel

\% Battelle 


\section{DISCLAIMER}

This report was prepared under the direction of the HANFORD ENVIRONMENTAL DOSE RECONSTRUCTION PROIECT Technical Steering Panel by Battelle Memorial Institute's Pacific Northwest Laboratories operating the Pacific Northwest Laboratory for the U.S. Department of Energy (DOE). While funding for the work was provided by DOE, the work is not under DOE direction or control. The views and opinions of the authors expressed in this document do not necessarily reflect those of the United States Government or any agency thereof. Reference herein to any specific commercial product, process or service by trade name, trademark, manufacturer or otherwise does not necessarily constitute or imply its endorsement, recommendation or favoring by the U.S. Government or any agency thereof, nor by Battelle Memorial Institute.

Printed in the United States of America

Available to DOE and DOE contractors from the

Office of Scientific and Technical Information, P.O. Box 62, Oak Ridge, IN 37831; prices available from (615) 576-8401. FTS 626-8401.

Available to the public from the National Technical Information Service,

U.S. Department of Commerce, 5285 Port Royal Rd., Springiield, VA 22161. 




PNL- - 7870-HEDR

DE92 010425

\title{
PROJECT MANAGEMENT PLAN \\ FOR THE HANFORD ENVIRONMENTAL DOSE RECONSTRUCTION PROJECT
}

\author{
D. B. Shipler
}

March 1992 
PROJECT MANAGEMENT PLAN FOR THE HANFORD ENVIRONMENTAL DOSE RECONSTRUCTION PROJECT

February 1992
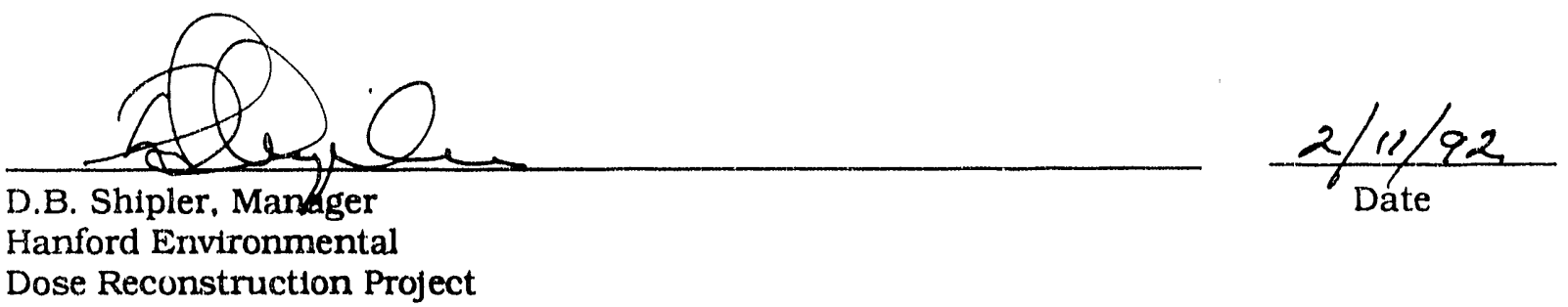

Hanford Environmental
Dose Reconstruction Project

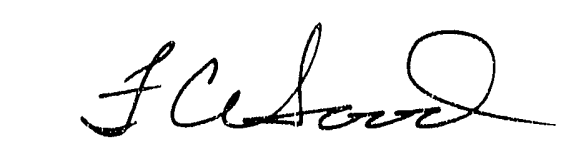

F.C. Hood, Director Quality Programs

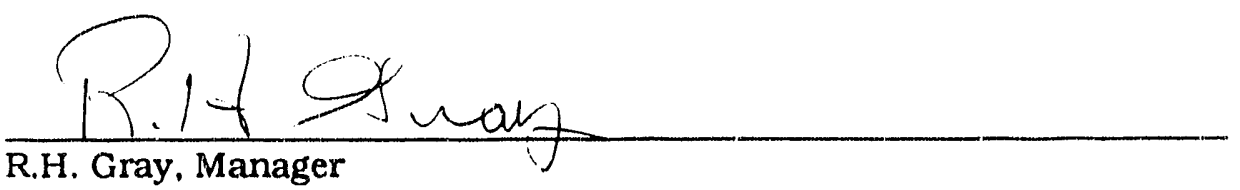

R.H. Gray, Manager

$\frac{z-11-9 z}{\text { Date }}$

Office of Hanford Environment

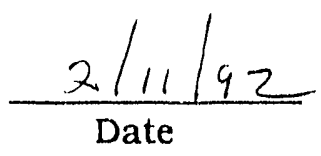




\section{CONTENTS}

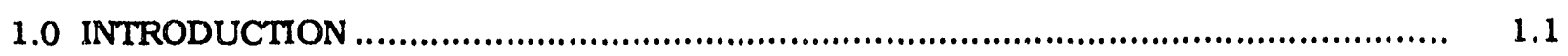

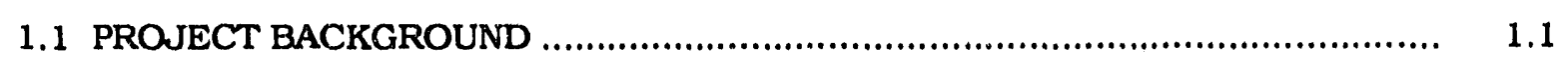

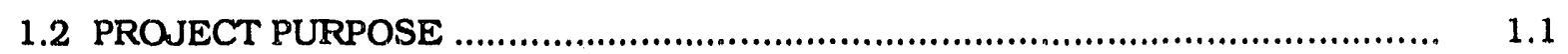

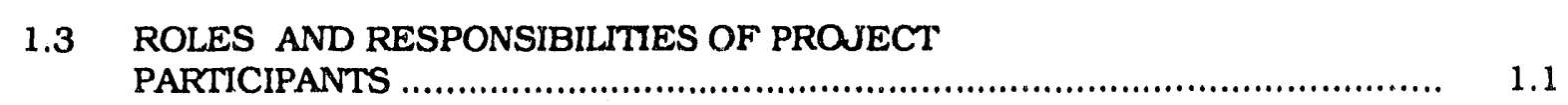

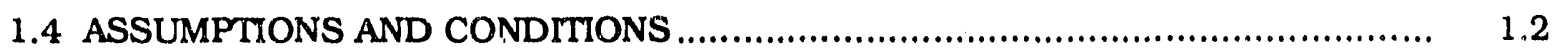

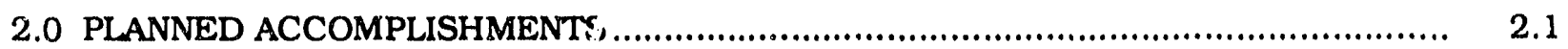

2.1 TECHNICAL AND COMMUNICATIONS OBJECTIVES .................................... 2.1

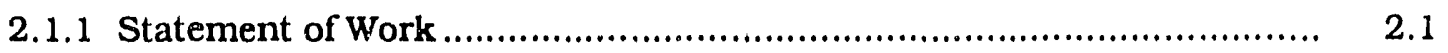

2.2 SCHEDULE OBJECTTVES ....................................................................... 2.3

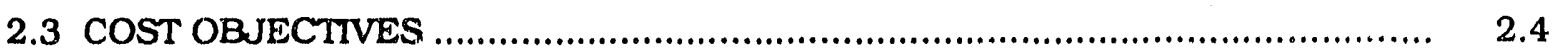

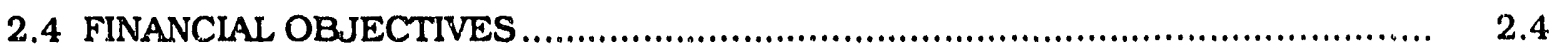

2.4.1 Funds Management ………….......................................................... $\quad 2.4$

3.0 MANAGEMENT SYSTEMS AND CONIROLS DESCRIPTIONS …............................. 3.1

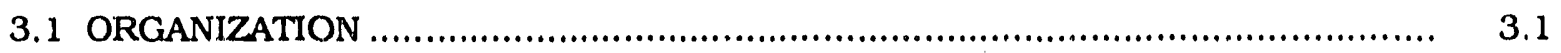

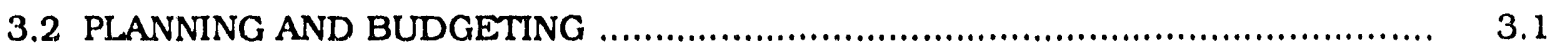

3.2.1 Work Authorization and Control …................................................... 3.1

3.2.2 Performance Measurement and Reporting .......................................... $\quad 3.5$

3.2.3 Contingency .................................................................................. 3.5

4.0 TECHNICAL SYSTEMS AND CONTROLS ……................................................. 4.1

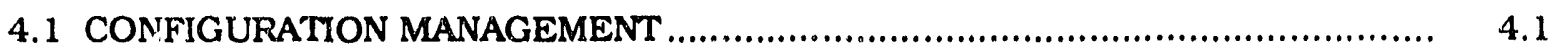

4.1.1 Change Control .............................................................................. 4.1



4.3 TECHNICAL PROCEDURES AND PLANS ……….......................................... 4.3

4.4 RECORDS AND INFORMATION MANAGEMENT …….................................. 


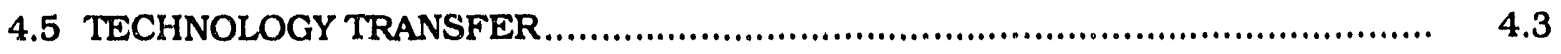

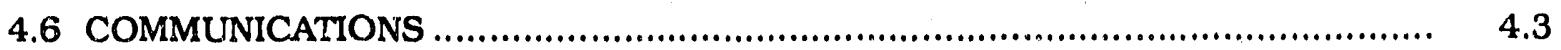

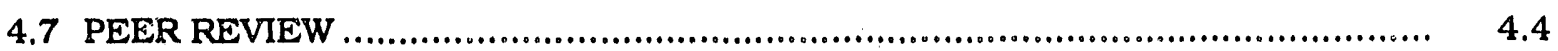

5.0 ADMINISTRATIVE SYSTEMS AND CONTROLS ................................................... 5.1

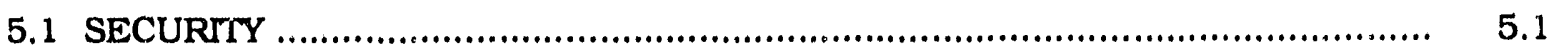



5.3 PERSONNEL ........................................................................................ 5.1

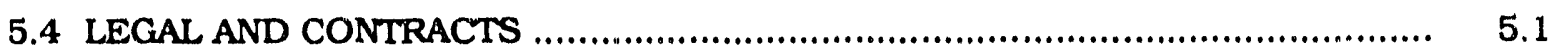

5.4.1 Legal ........................................................................................ 5.1

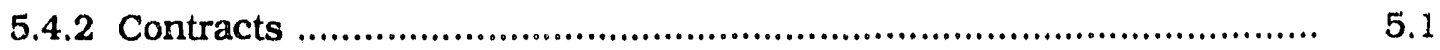

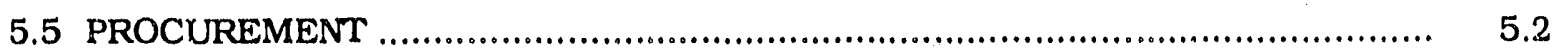

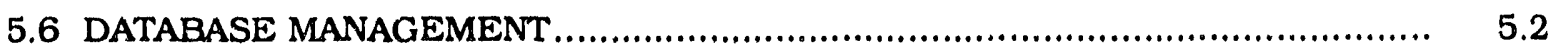

5.6.1 Administrative Databases ................................................................. 5.3

5.6.2 Technical Databases ....................................................................... 5.3

5.6.3 Communications Databases ........................................................... 5.3

5.7 PROPERTY MANAGEMENT ....................................................................... 5.3

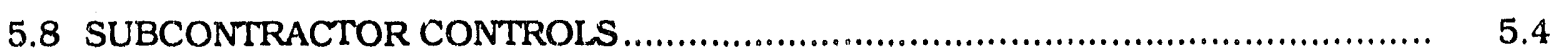

5.9 COMMITMENT CONTROL ....................................................................... 5.4

APPENDIX A - PROJECT WORK BREAKDOWN STRUCTURE AND TASKS ...................... A.1

APPENDIX B - PROJECT SUMMARY SCHEDULE …............................................... B.1

APPENDIX C - BATTELLE HEDR SPEND PLAN .................................................... C. 1

APPENDIX D - OUTIINE FOR MONTHLY REPORT INPUT, BY TASK.

D. 1

APPENDIX E - CHANGE REQUEST RECORD AND CHANGE

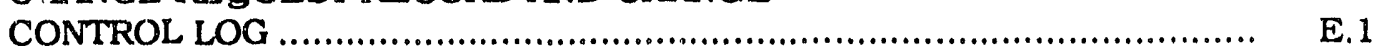

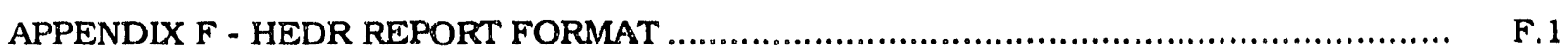

APPENDIX G - HEDR PROJECT ACTION TRACKING SYSTEM .................................... G. 


\section{FIGURES}



2.1 Summary-Level Work Breakdown Structure for the HEDR Project ........................ 2.2

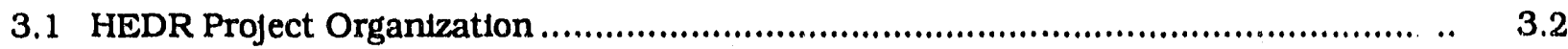

3.2 Process for Planning, Authorzing, and Completing HEDR Work ......................... 3.4

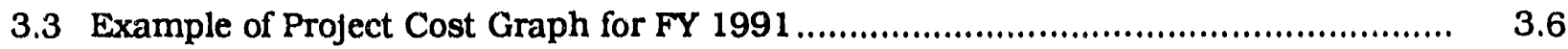

4.1 HEDR Project Document Hierarchy ............................................................ 4.2



\section{TABLES}

3.1 Responsibility, Accountability, and Authority Matrix ...................................... 3.3

5.1 Battelle Organization Responsibility for HEDR Acttvities ............................... 5.2

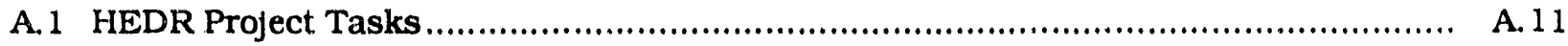

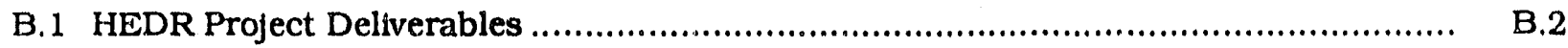




\subsection{INTRODUCTION}

This Project Management Plan (PMP) describes the approach that will be used to manage the Hanford Environmental Dose Reconstruction (HEDR) Project. The plan describes the management structure and the technical and administrattve control systems that will be used to plan and control the HEDR Project performance. The plan also describes the relationship among key project particlpants: Battelle, the Centers for Disease Control (CDC), and the Technical Steering Panel (TSP).

The PMP includes the following sections:

- Introduction (Section 1.0). Summarizes the project's purpose, scope, and the role of project participants.

- Planned Accomplishments (Section 2.0). Addresses HEDR Project objectives, including technical, cost, and schedule objecttves.

- Management Systems and Controls Descrtption (Section 3.0). Depicts the project work scope elements, participants, and relationships established to achieve the project objecttves.

- Technical Systems and Controls (Section 4.0). Documents the overall approach used in establishing and controlling project baselines and integrating the technical task plans and measurement techniques.

- Administrative Systems and Controls (Section 5.0). Documents technical support systems used in the planning and performance of work.

\subsection{PROJECT BACKGROUND}

The HEDR Project was prompted by mounting concern by the public about possible health effects from more than 40 years of releases of radioactive materials from the Hanford Site. In 1986, the Hanford Health Effects Review Panel recommended that a dose reconstruction study be conducted. The study was begun in 1987 . When cornpleted in 1995. the project will provide dose estimates for the Hanford Thyrold Disease Study, specifled populations, reference individuals, and actual indtviduals as well as a dose estirnating capabulity (software and data bases). At project. completion, the dose estimate model will be transferred to another agency that can provide dose estimates for individuals and other doserelated data upon request.

\subsection{PROJECT PURPOSE}

The HEDR Project was established to develop estimates of radiation doses that populations and individuals could have received from releases of radioactive materials from the Hanford Site since 1944, with descriptions of the uncertainties inherent in such estimates.

\subsection{ROLES AND RESPONSIBILTIES OF PROJECT PARTICIPANTS}

Major project participants are shown in Figure 1.1. Beginning in February or March 1992. Battelle Pacific Northwest Laboratories staff will conduct the work under contract to the CDC. The TSP directs and approves the

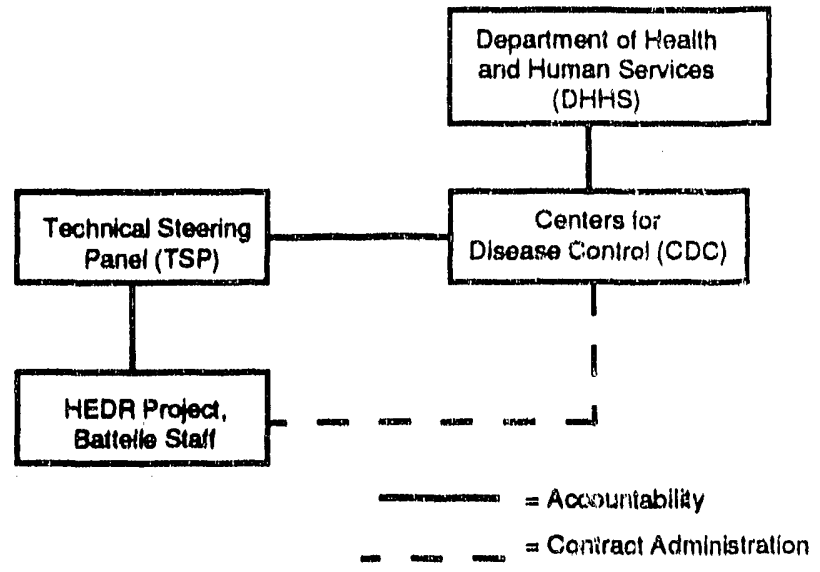

FIGURE 1.1. Major HEDR Project Participants 
work. The DOE funds the work through a Memorandum of Understanding with the U.S. Department of Health and Human Services (DHHS). The CDC is an agency of the Public Health Service, which is part of the DHHS. The DOE ensures accountability through its contracts. The DOE has no review or approval authority for the work.

More detail on project participants is provided in Section 3.1, Organization.

\subsection{ASSUMPTIONS AND CONDITIONS}

Project planning is based on TSP Research Directive 90-1. "Project Direction," which establishes a planning process, content of project plans, and a process for tracking and reporting project work.
Project funding, which currently comes directly through DOE, will change in February or March 1992, when Battelle will contract with the CDC to continue the dose reconstruction work. Additional detall is provided in Section 2.3, Cost Objectives.

The PMP will be updated as required, at least annually. Controlled coples of the PMP are kept by HEDR staff, the Battelle Records Center, the TSP and its staff, and the DOE Richland Field Office Public Reading Room. Updated portions of the PMP will be distributed through Battelle's Document Control Center. 


\subsection{PLANNED ACCOMPLISHMENTS}

This section describes the technical, communications, schedule, cost, and financial othectives of the project. A project work breakdown structure (WBS) is provided in Appendix A. Appendix B contains the Project Summary Schedule and milestone descriptions. Appendix $\mathrm{C}$ contains a time-phased bidget at: the task level for FY 1992, FY 1993. and the first half of FY 1994. For planning piurposes, fiscal years begin on October 1 of ohe year and end on September 30 of the following year.

\subsection{TECHNICAL AND COMNUNICATIONS OBJECTIVES}

The overall technical objective of the HEDR Project is to estimate doses, and their uncertainties, to populations and individuals from past Hanford releases. More detalled objectives, set by the TSP in February, 1991, are as follows:

- demonstrate that sufficient historical information exdsts or can be reconstructed to enable a dose reconstruction study to be cer rried out

- reconstruct release information--what was released, from where, how much, and when-from Hanford facilities, $1944-1990$

- develop a maintainable dosimetry and information system that can estimate doses to special populations and to representative and actual individuals, given personal information such as age, locations, lifestyle, and dietary habits

- develop conceptual and computational models to spectfically deal with uncertaintles in the variables needed to estimate historical doses to offsite populations

- estimate radiation doses that can be used by the Fred Hutchinson Cancer Research Center in its Hanford Thyroid Disease Study and by other potential health studies
- support Native American tribal research, conducted by tribes, to acquire demographic, food consumption, and other dose input data

- perform quality and credible science

- communicate with the public

- set standards for conducting a public study.

Section 2.1.1 describes the work necessary to produce the products and services to meet these objectives.

\subsubsection{Statement of Work}

A summary-level WBS is shown as Figure 2.1: the full WBS is in Appendix A.

Tasks are developed in the organizational structure to address planned work of the WBS.

The following discussion summarzes each of the HEDR tasks.

- Project Management (WBS 1.0) - provides project planning, control, and management of Battelle dose reconstruction work in accordance with TSP direction.

- Technical Integration (WBS 2.0) - provides technical overview of the project to ensure that appropriate technical activities are planned, that appropriate information is generated, and that technical task work is integrated effectively for developing the project dose estimating capabilities and for performing the final dose calculations.

- Source Terms (WBS 3.0) - develops est1mates of radioactive missions since 1944 from Hanford facilities based on historical measurements and production information. Source term estimates are used by Environmental Transport Task members to reconstruct the concentrations of radionuclides in the environment. 


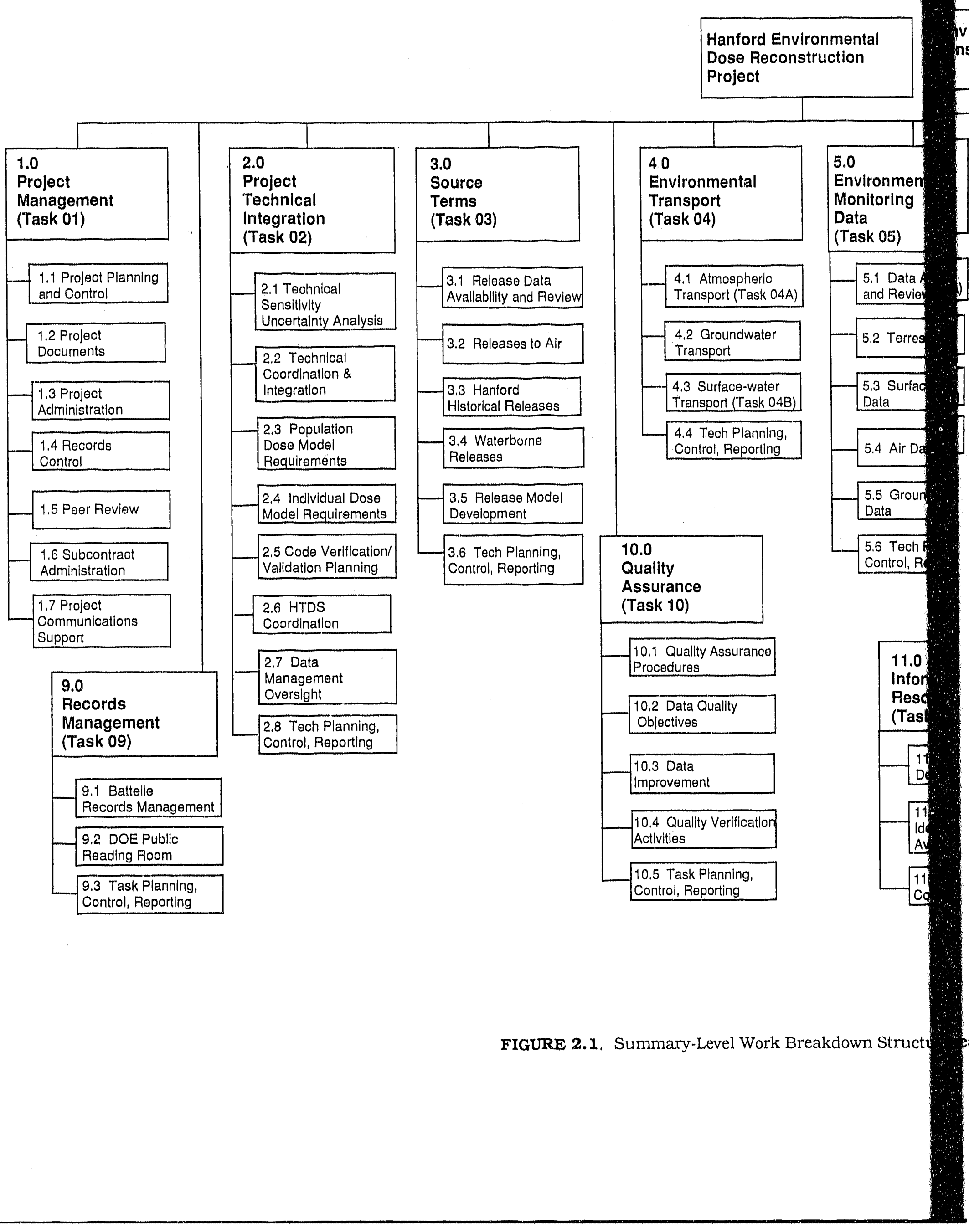




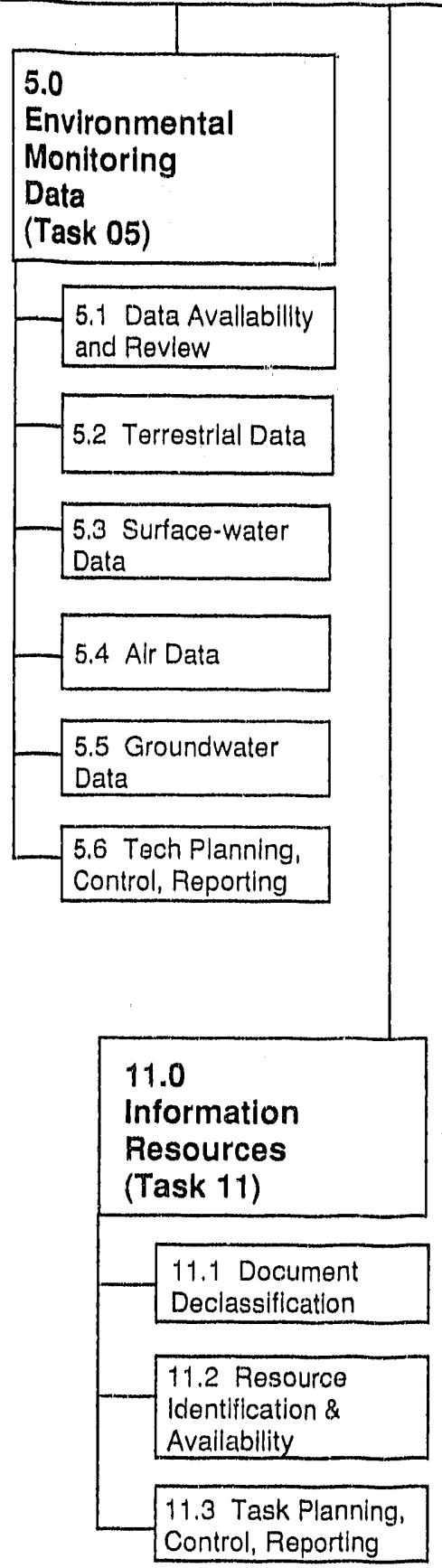

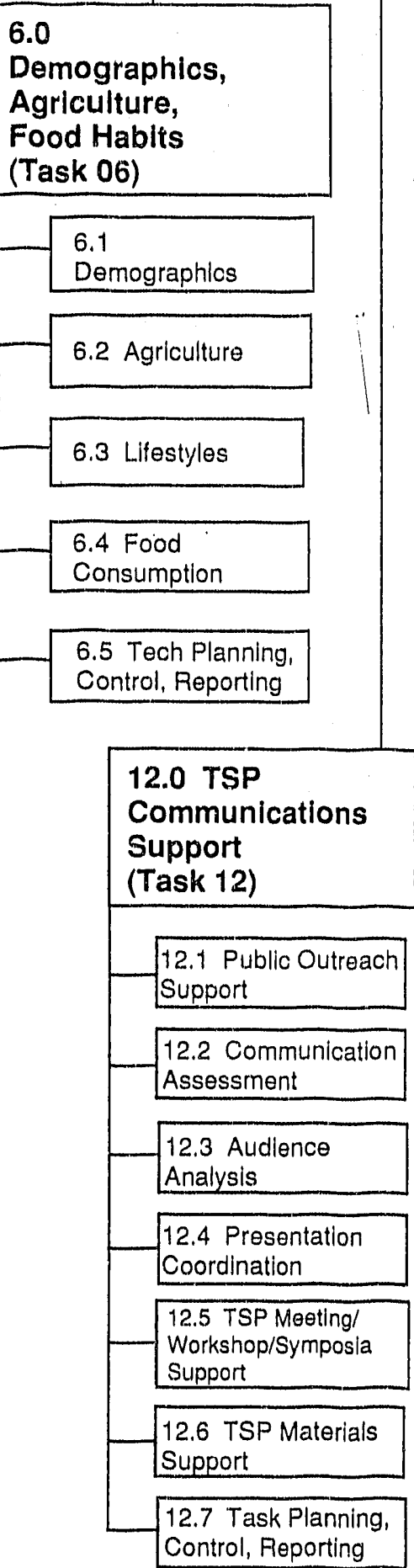

\section{0}

Environmental

Pathways and

Dose Estimates

(Task 07)

\begin{tabular}{l}
\hline $\begin{array}{l}7.1 \text { Code } \\
\text { Development }\end{array}$ \\
$\begin{array}{l}7.2 \text { Dose } \\
\text { Calculatlons }\end{array}$ \\
$\begin{array}{l}7.3 \text { Model Parameter } \\
\text { Development }\end{array}$ \\
$\begin{array}{l}7.4 \text { Tech Planning, } \\
\text { Control, Reporting }\end{array}$ \\
\hline
\end{tabular}

8.0

Statistics

Support

(Task 08)

8.1 Technical

Integration (Task 02)

8.2 Source Terms

(Task 03)

8.3 Environmental

Transport (Task 04;

8.4 Environmental

Monltoring Data (Task 05)

8.5 Demographlcs,

Agriculture, Food Habits (Task 06)

8.6 Environmental Pathways and Dose Estimates (Task 07)

8.7 Tech Planning, Control, Reporting

eakdown Structure for the HEDR Project 
- Atmospheric Transport (WBS 4.1) - reconstructs the movement of radioactive materials (source term information) from areas of release through the atmosphere to the environment. The results of the analyses are concentrations in envirorimental media, which are used by pathways codes to generate estimates of concentrations in humans.

- Columbir River Transport (WBS 4.2) - reconstructs the movement of radioactive materials (source term information) from areas of release through the Columbia River to other environmental media. The resu's of the analyses are concentrations in environmental media, which are used by pathways codes to generate estirnates of concentrations in humans.

- Environmental Monitoring Data (WBS 5.0) assembles, evaluates, and summarizes key historical measurements of the concentrations of radionuclides in the environment around the Hanford Site. Measurements are of air, drinking water, foods, fish, the Columbia River, soll, and other materials. Measure. ments are evaluated to estimate their accuracies and then used by the Environmental Pathways and Dose Estimates Task to est1mate radiation doses and by the Atmospheric Transport and Columbia River Transport Tasks to calibrate computer models.

- Demography, Food Consumption and Agrtculture (WBS 6.0) - develops demographic. lifestyle, food consumption, and food production information needed to estimate doses. Such information is developed for the general population and for special groups such as Native American tribes.

- Envtronmental Pathways and Dose Esttmates (WBS 7.0) - uses calculated and measured concentrations of radionuclides provided by the Atmospheric Transport Task, the Columbla River Transport Task, and the Environmental Monitoring Data Task to calculate doses to populations, typical individuals, and specific individuals.

- Statistics (WBS 8.0) - provides statistical support to members of technical tasks. Task work also includes conducting sensitivity and uncertainty analyses, which are used to identify the most significant input parameters.

- Records Management (WBS 9.0) - stores and controls completed project records, maintains an automated inventory of all project documents, and provides a reference service to project staff and the TSP.

- Quality Assurance (WBS 10.0) - ensures continuous quality assurance (QA) support and coordination with all project tasks. Work includes developing a project $\mathrm{BA}$ plan and monitoring project activities to ensure compliance with the plan.

- Information Resources (WBS 11.0) searches for, retrleves, declassifies as necessary, and distributes Hanford-originated documents of use to HEDR staff for dose reconstruction. Coples of information used and declassified are also made publicly avallable to the public.

- TSP Communications Support (WBS 12.0) assists the TSP in developing, implementing, and evaluating its public involvement program.

\subsection{SCHEDURE OBJECTIVES}

The Project Summary Schedule, in Appendix B, shows major work activities, milestones, and constraints for the project through its completion in 1995, though Battelle's contract with CDC is currently expected to run only through February 1994. The schedule and its associated work scopes, etc., can be changed through contract modification or when the contract is renewed.

A computerized, integrated scope, cost, and schedule is maintained of approved task activittes and budgets. The schedule is controlled to provide a basis for change reviews and detai'ed planning for out years. It is also used for evaluation of alternatives and of the impacts of propused decisions. 


\subsection{COST ORJECTIVES}

The Battelle HEDR spend plan (budget) for FY 1992, 1993, and the first half of FY 1994 is contained in Appendix $\mathrm{C}$. The budget for the first half of FY 1994 will be negotiated as part of the Battelle/CDC contracting process. The budgets for the second half of FY 1994 and FY 1995 have not yet been developed by the TSP.

\subsection{FINANCIAL OBJECTIVES}

The project has been funded directly by the DOE since it began in 1987. In December of 1990, DOE and the Department of Health and Human Services (DHHS) entered into a Memorandum of Understanding whereby the DHHS assumed management of dose reconstruction projects related to DOE facilities. The HEDR Project will continue to be funded directly by DOE through the RL, Financial (FIN) Plan through February - March 1992. Within the DHHS, the Centers for Disease Control (CDC) will manage the work of Battelle on the project. CDC will have a sole-source contract with Battelle for the remaining HEDR technical work. The contract is expected to be a costplus-fixed-fee contract for 2 years with options for any new or remaining work CDC deems needed. This contract will be under Battelle's 1831 contract with DOE and will be funded directly by CDC. DOE will provide funds to $\mathrm{CDC}$ for Battelle's contract.

Total project cost through FY 1991 is $\$ 13.1 \mathrm{M}$ (or 12.7M, excluding FY 1987). TSPapproved project budgets for FY 1992 and
1993 are $\$ 5.022 \mathrm{M}$ and $\$ 5.36 \mathrm{M}$, respecttvely. Anticipated budgets for FY 1994 and 1995 are in the range of $\$ 5-6 \mathrm{M}$, bringing total escimated project cost to completion in the range of $\$ 33$ $34 \mathrm{M}$. Of this amount, Battelle has spent $\$ 11.2 \mathrm{M}$ through FY 1991 and has approved budgets of $\$ 3.8 \mathrm{M}$ and 4.1M for FY 1992 and 1993, respectively. Estimates for FY 1994 and 1995 are in the range of $\$ 3-4 \mathrm{M}$ each, bringing Battelle's estimated cost to completion to 26.7M. The spend plan for Battelle, through Mid-FY 1994, is given in Appendix C.

\subsubsection{Funds Management}

One-half of the DOE FY 1992 funds (\$2 M) (October 1991 through March 1992) has been provlded by DOE-EH 42 (DOE-Headquarters) in the 1992 FIN Plan to the U.S. DOE Richland Fleld Office (RL). RL has provided the funds to Battelle through the 1830 contract. The remaining one-haif of DOE FY 1992 funds has been transferred to the DHHS/CDC to be provided to Battelle, the TSP, and participating Nattve American tribes, but these funds have not yet been placed through $\mathrm{CDC}$ contracts. A Battelle/CDC contract is expected to be in place in February or March 1992. Funding for FY 1993 and contracted portions of FY 1994 will be incrementally funded by $C D C$ based on TSP-approved fiscal year Task Plans. Spending of fiscal year funds will be reported in monthly reports to the TSP. 


\subsection{MANAGEMENT SYSTEMS AND CONTROLS DESCRIPTIONS}

Project management systems will be used to plan and budget work; establish technical. schedule, and cost plans; establish performance criterla; status actual performance against approved plans; control changes, and assign organizational accountability. The following sections describe the systems and processes used by Battelle to perform and control work and how Battelle interacts with the TSP and CDC to plan, report, and complete work. This process between Battelle and the TSP is used now, and the CDC will assume its role when the contract is signed.

\subsection{ORGANIZATION}

A project organization chart is shown in Figure 3.1. Responsibilities of key individuals are shown in Table 3.1.

Battelle has provided all subcontracting for the project to date. Subcontracts have been provided for the TSP. TSP staff support. TSP communications support, meetings and research by Native American tribes, and Battelle technical support. The types of subcontracts used include workshop agreements, interlaboratory agreements, research agreements, negotiated scope and cost contracts, and indefinite-quantity contracts. The numbers of each type of contract normally placed each year have been approximately the following:

- negotiated scope contracts (30) - where the statement of work is negotiated

- inter-laboratory agreements (3) - where work is arranged with another Battelle component, such as the Battelle Seattle Research Center

- indefinite-quantity contracts (4) - where work orders are issued as services are known; the total number of hours required is not known. Can be sole source or competttive bid.

- research agreements (3) - to conduct research for a Battelle-spectfled scope of work. e.g., a university would develop historical agricultural information for use in dose estumates.

- workshop agreements (60) - where travel and living expenses, and sometimes a fee, are paid to an individual for attending/presenting at seminars or workshops.

Subcontracts for the TSP, TSP staff support. TSP communications support, and Native American tribes (meetings and research) will not be managed by Battelle under its contract with CDC, which is expected to be in place by February or March 1992. Battelle will subcontract only for support necessary to meet its technical needs.

\subsection{PLANNING AND BUDGETING}

\subsubsection{Work Authorization and Control}

Work scopes, technical approaches, quality objectives, milestones, deliverables, and estimated costs are developed with the TSP and approved by the TSP as fiscal year Task Plans.

Task Leaders, as shown in Figure 3.1, are responsible for evaluating their Task/Subtask Plans and determining the most effective way to authorize and track specific scopes and technical approaches of the work. This evaluation results in defining financial work packages and allocating the budget for reporting and tracking. These proposed work packages are reviewed for feasibility of implementation by the Project Coordinator (see Figure 3.1 box called "Project Coordination") and approved by the Project Manager.

The Project Coordinator assigns numbers to the work packages, issues the numbers to the Task Leaders, provides the numbers to Battelle Finance, and requests financial reports from Battelle Cost Accounting. Task Leaders and the Project Office recelve bi-weekly cost reports and monthly reports that compare actual versus budgeted costs. These reports 


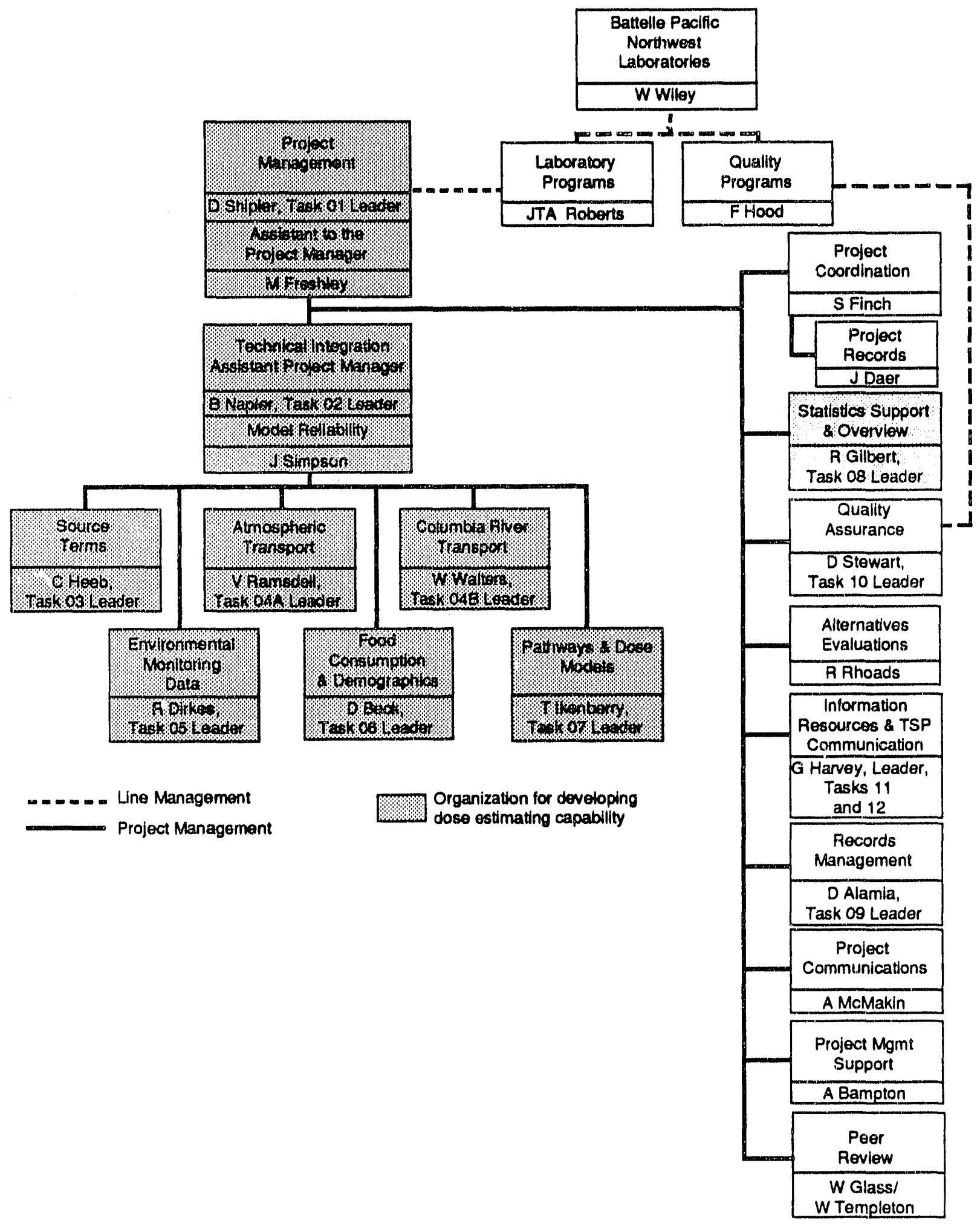

S91 10023.5

FIGURE 3.1. HEDR Project Organization 


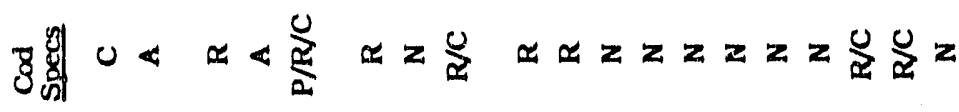



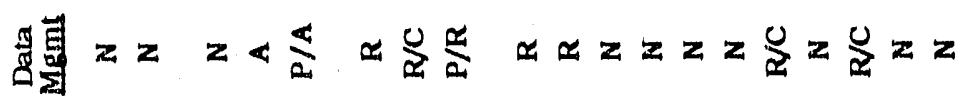

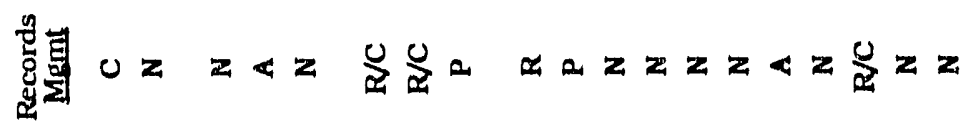

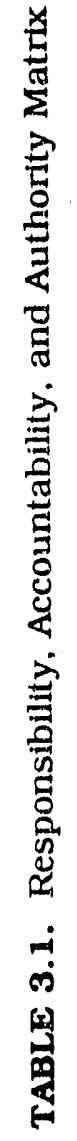

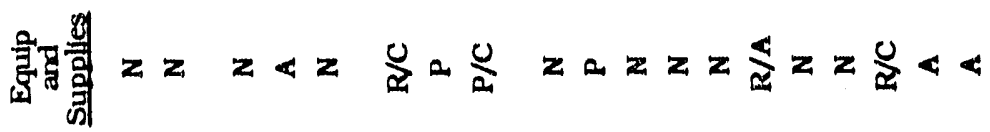

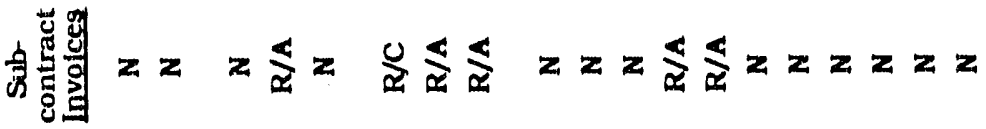



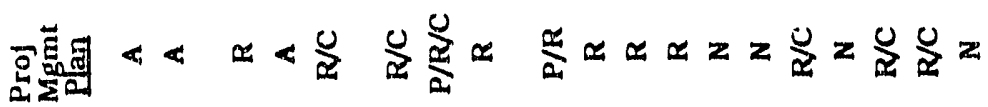

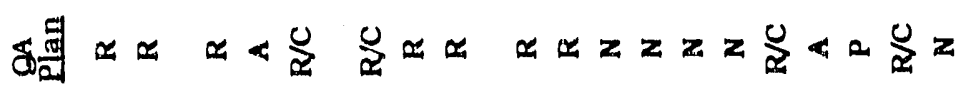

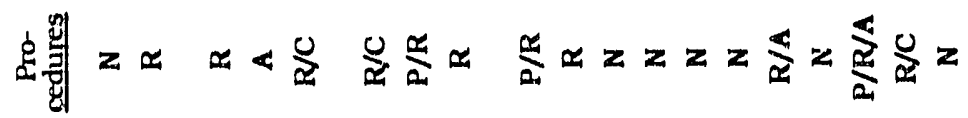

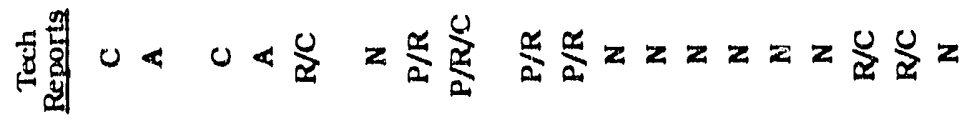

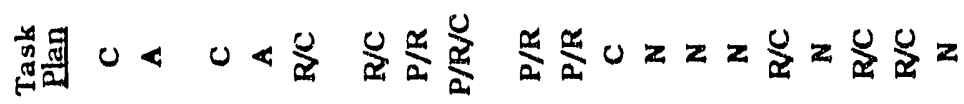

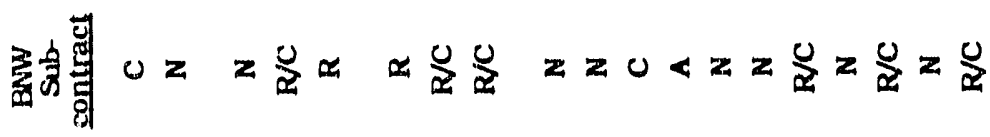

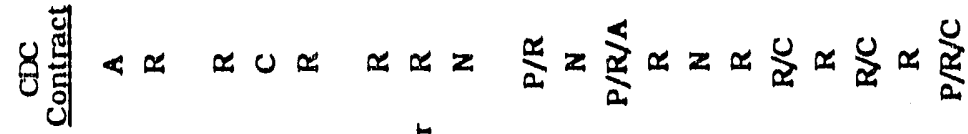

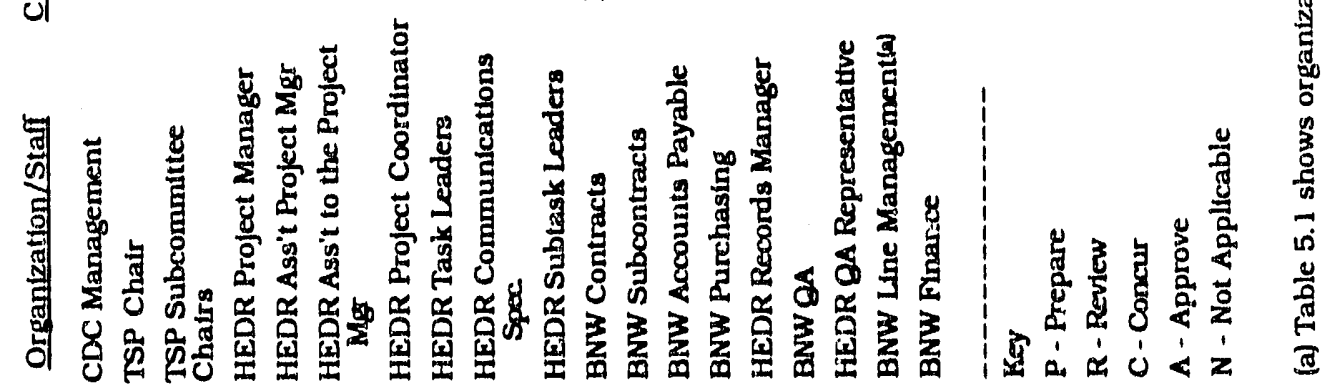


are reviewed and tracked by the Task Leaders and revlewed with the Project Coordinator and Project Manager as part of internal, monthly HEDR team meetings.

In addition to the task plans, other HEDR planning documents describe how work is conducted. These documents are described in Section 4.3. Work authority is shown in Figure 3.2. The process for authordzing Battelle to conduct HEDR work is as follows.

\section{Planning the Work (Steps 1 through 8 in Figure 3.2)}

The CDC ensures accountability and provides contract administration for HEDR work in accordance with the DOE/ DHHS Memorandum of Understanding, $\mathrm{CDC}$ policles and procedures, and the $\mathrm{CDC} /$ Battelle contract. The TSP defines the scope of work, deliverable items, and work schedule in writing to Battelle. Battelle develops detalled task plans based on the TSP guldance. The task plans define the scope, deliverables, and schedule in more detail and include technical approach, quality assurance considerations, and staff organization of specific activities. The TSP and the $\mathrm{CDC}$ review and comment on the task plans, and Battelle revises them accordingly. The revised plans are reviewed by the TSP and the CDC, approved by the TSP, and concurred with by the CDC.

\section{Authorizing the Work (Steps 7 through 10 in Figure 3.2)}

The TSP authorizes the technical work to proceed by signing approved task plans. The $\mathrm{CDC}$ orders the work to proceed through the Battelle contract. The Battelle Project Manager authorizes HEDR staff to proceed with the work by authorization of funds through work packages.

\section{Reviewing and Approving Changes to Work (Steps 11 and 12 in Figure 3.2)}

Once the approved work is under way the TSP may modify technical emphasis or deliverables within the scope, schedule, or deliverables of the Battelle contract. Any changes to

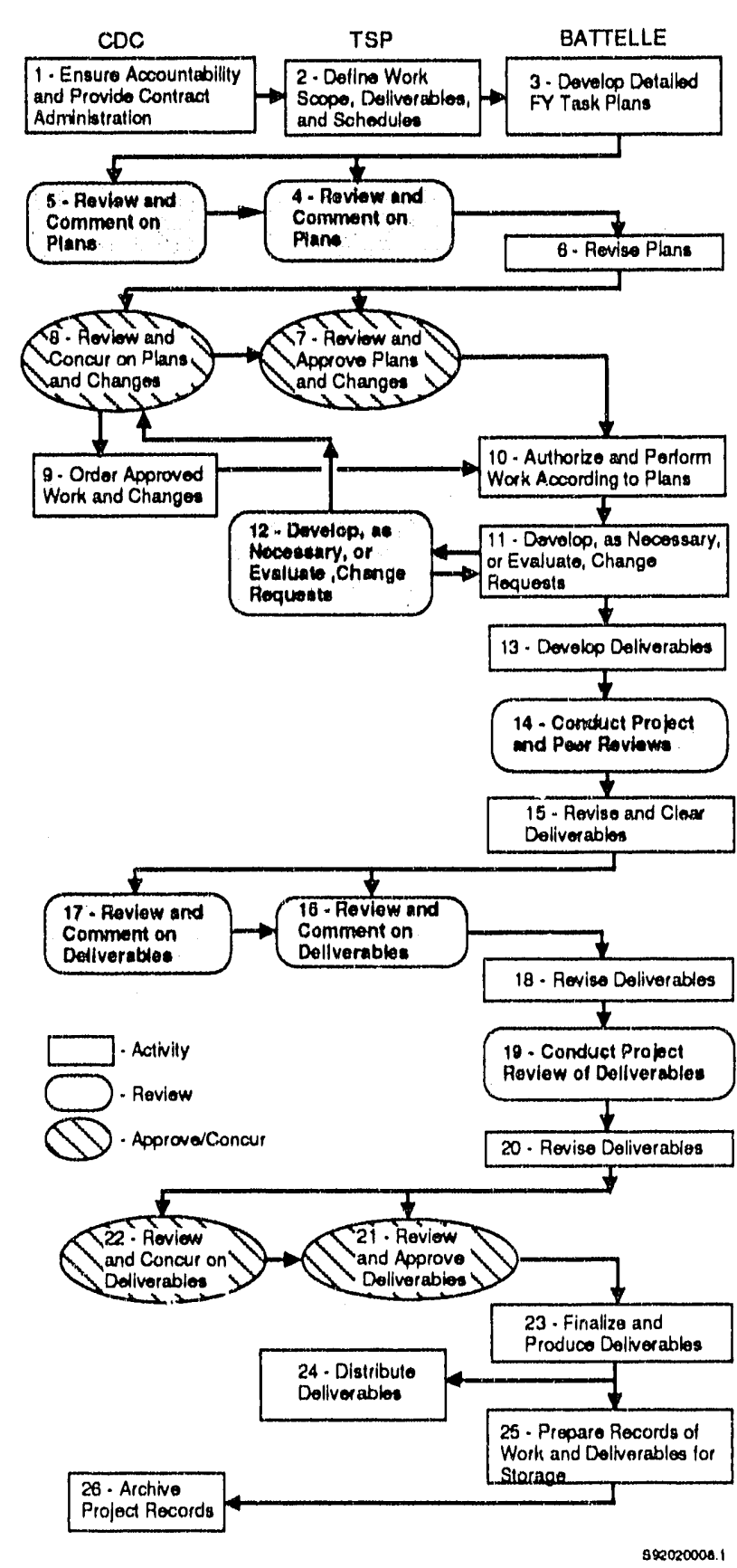

FIGURE 3.2. Process for Planning, Authorking, and Completing HEDR Work 
the conditions of the contract are proposed to the TSP by Battelle through written change requests (see form in Appendix E). The TSP evaluates and approves or disapproves Class 1 change requests (see Section 4.1.1). The CDC revlews and concurs with the TSP's action and modifles the Battelle contract, as appropriate.

\section{Carrying out and Dellvering the Work (Steps 13-24 in Figure 3.2)}

As approved work continues, Battelle generates deliverable items to the TSP and CDC as agreed to in the task plans and contract. Before a deliverable goes to the TSP and CDC (and is made publicly available), Battelle conducts project and peer reviews of it, then revises tt to respond to review comments. The deliverable is then cleared within Battelle as a draft version. The TSP and CDC review and comment on the draft deliverable, which is also made publicly available at this point. Battelle revises the deliverable to respond to TSP and CDC comments. A projest review then occurs. The deliverable is revised based on the results of the project review, if necessary. The revised deliverable is reviewed by the TSP and CDC, approved by the TSP and concurred with by the CDC. The deliverable document is finalized, produced as a final item, and distributed by the TSP.

\section{Creating and Archiving Project Records (Steps 25 and 26 rigure 3.2)}

Records of the work documented in the deliverable are prepared for storage and archived according to Battelle's contract and HEDR procedures.

\subsubsection{Performance Measurement and Reporting}

Project performance is measured at the end of each month and reported in the HEDR monthly report. Each task reports progress and work status as shown in Appendix D.
Cost performance is reported as shown in Figure 3.3. This graph is filled in with the appropriate costs (monthly and cumulative) and appears in each HEDR monthly report.

Project performance is measured as percent complete by comparing costs (planned versus actual) and schedule (milestone) to the scope of work. Monthly reports show cumulative varlances that are $15 \%$ or $\$ 25,000$ over or under the budgeted cumulative amount, whichever is smaller. Monthly reports from Task Leaders to the Project Manager also include a discussion of monthly variances of $10 \%$ or $\$ 5,000$, whichever is smaller.

Part of monthly reporting is the detalled analysis of real or potential variances and corrective action planning to prevent the varlance or get the activity back on schedule.

\subsubsection{Contingency}

Contingency funds for Battelle work are proposed by the Project Manager and approved by the TSP as part of the fiscal year task planning process. As fiscal year work proceeds and needs are tdentifled, requests for allocation of contingency funds to Task/Subtask Plans are made to the TSP by the Project Manager. These requests are usually made prior to the April and July TSP meetings. Reallocation of budgeted Task/Subtask Plan funds may also be requested at these times.

Following approval of allocation of contingency or prevlously budgeted funds, Battelle revises the Task Plans and submits them to the TSP for approval. 


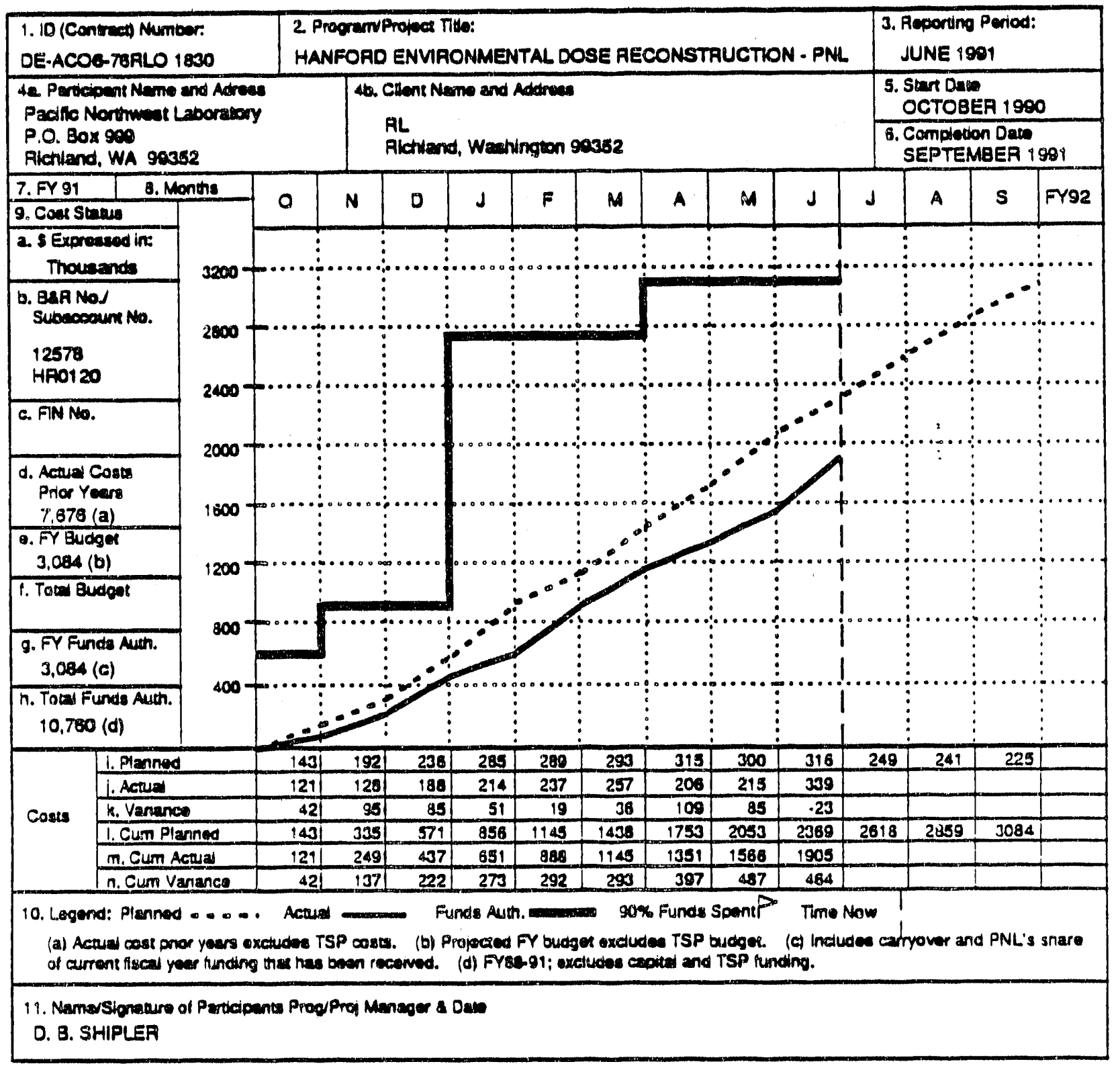

FIGURe 3.3. Example of Project Cost Graph for FY 1991 


\subsection{TECHINICAI, SYSTEMS AND CONTROLS}

\subsection{CONFIGURATION MANAGEMENT}

Configuration management principles are applied to HEDR Project activities as necessary to ensure that requirements and the technical scope are adequately defined, documented. controlled, and can be audited. Project scope, technical approach, quality objectives, milestones, and dellverables are developed, controlled, and changed in the planning process approved by the TSP as discussed in Section 3.0.

Project deliverables to be designed, developed, and controlled are computer codes and their related files and databases. The HEDR Quality Assurance Plan stipulates that Battelle's Software Control Procedures (SCP-70. 312 through 318 , as shown in Figure 4.1) will be implemented to ensure that requirements are documented, designs are revlewed, test results are recorded, verification and validation activities are carried out, and changes are controlled.

Controlling technical work is essential to developing and maintaining quality, credibllity, and defensibility of technical deliverables. HEDR technical systems and controls are designed and implemented to ensure that the performance of work is designed, carried out, and documented as planned, continuously reviewed in progress, and peer revlewed prior to submittal. The control of changes that affect the approved technical scope is exercised through the change control process, as discussed in the following sections.

\subsubsection{Change Control}

Revisions to Project and/or TSP approved HEDR requirements, technical scope, approach, deliverables, schedules, and budgets, are managed in a disciplined manner. The change control process requires that a proposed change be identifled, defined, documented, reviewed and approved or disapproved, and that implementation of changes be traceable to controlled documents.

There are two classes of changes: affecting approved task plans and thus requiring TSP approval (Class 1), and internal changes requiring only Project Manager approval (Class 2). Thresholds for class 1 changes are 1) any change in scope, technical approach, data quality objectives, or milestone defraction from approved task plan, 2) any change in milestone schedules of approved task plans greater than one month, or 3) any increase in subtask budgets of approved task plans of more than $10 \%$ or $\$ 10 \mathrm{~K}$, whichever is less.

Thresholds for class 2 changes are 1) changes in scope, approach, data quality objectives, or milestone definitions not alfecting statements in TSP-approved task plans but affecting staffing, equipment, durations, interfaces, or constraints of TSP-approved subtask plans, 2) any changes in milestone schedules of approved task plans greater than 2 weeks, or 3) any increase in subtask budgets of approved task plans of more than $5 \%$ or $\$ 5 \mathrm{~K}$, whichever is less.

Change requests are initialed by Subtäsk Leaders and reviewed and concurred with by the cognizant Task Leader. The Task Leader forwards the request to the Project Manager, who initiates a review by the Assistant Project Manager, the Statistics Task Leader, the Project Coordinator, and other Project Leaders as deemed appropriate. The Project Manager approves necessary class 2 changes. Necessary class 1 changes are concurred with by the Project Manager, and the request is implemented and submitted to the TSP. The TSP is expected to take action on the request at its next, regular meeting.

The planning, change request, review and approval, and work authorization process is described in Section 3.2, Work Authortzations. 




FIGURE 4.1. HEDR Project Document Hierarchy

Changes are requested in writing, approved by recorded action of the Project Manager and/or the TSP, and implemented through fiscal year Task Plans and their revisions.

Change control of HEDR-developed software is performed and documented in accordance with SCP-70-314.

See Appendix $\mathrm{E}$ for Change Request Record and Change Control Log.

\section{2 gUAIITY ASSURANCE}

Quality assurance $(\mathrm{BA})$ requirements for the HEDR Project, including requirements for data quality objectives, are contained in the HEDR Quality Assurance Plan. Requirements applicable to subcontracts are described in individual Statements of Work in each subcontract or in supplements to each subcontract.

Findings, observations, and concerns identified during audits, surveillances, and continuous support activities are logged and corrective actions are planned and tracked to prevent occurrence or recurrence of nonconformances, as the case may be.

The project provides indoctrination and training of personnel performing activities affecting quality to ensure that suitable proficlency is achieved and maintained. Personnel are trained in appropriate procidures.

The QA requirements established for the HEDR Project also address ongoing verification of compliance to established requirements. These verifications are performed on a focused, real-time basis in the form of surveillances and on a broader, retrospective basis in the form of audits. In addition, as shown in Figure 3.1 , a quality engineer is assigned to the project to assist with implementing $Q A$ requirements and meeting project $\mathrm{QA}$ objectives. 


\subsection{TECHNICAZ PROCEDURES AND PLANS}

The key functions of the project are expressed in the serles of documents shown in Figure 4.1. The controlling document for the project is this Project Management Plan. Other key documents include a Quality Assurance Plan, Code Design Specifications, Records Management Plan, Information Acquisition Plan, and a Peer Review Protocol.

These documents flow down from similar Battelle documents and implement the appropriate Battelle requirements. (For example, the HEDR Project QA Plan tailors Battelle QA requirements to fit specific aspects of the HEDR Project.) The uniqueness of the HEDR Project has required additional documents, such as the Information Acquisition Plan, which addresses searching for, retrleving, and evaluating of Hanford-generated historical docurnents.

Procedures for implementing the requirements of these plans have been adopted from Battelle procedures or developed to meet specific or unique project needs. The procedures applicable to each plan are also shown in Figure 4.1.

Most Battelle and HEDR Project plans and procedures are controlled and distributed by Battelle Document Control to ensure that current requirements are avallable to responsible project staff as needed. Projectcontrolled plans and procedures are Identified in Figure 4.1.

\subsection{RECORDS AND INFORMATION MANAGEMENT}

The project implements documented Battelle records arrangement requirements. Records management procedures for the HEDR Project are contalned in a Records Management Plan (RMP 1-Rev 1). The project maintalns a Records Inventory and Disposition Schedule in accordance with documented requirements.

\subsection{TECHNOLOGY TRANSFER}

Several HEDR-developed technologies will be transferred to other organizations near project completion. They include models for source terms, atmospheric transport and dispersion, Columbia Rtver transport and dili.1tion, exposure pathways, and dose. These models provide input to and estimation of doses to real and representative individuals who lived in a particular area. Along with the computer codes will be many extensive data bases and files of information reconstructed to represent the atmospherlc, demographlc, agricultural, and other spatial and temporal geographic information of the area surrounding the Hanford site since operations began. A key element of technology transfer will be the statistical handling of this immense generation, reconstruction, and compilation of data and the statistical handling of the data by the computer codes. All this technology was developed to ensure the accuracy and precision of dose estimates. The resulting transferred technologies and data bases will represent the leading edge of the dose estimating field.

\subsection{COMUTUNICATIONS}

HEDR Procedures govern project commund. cations, such as the use of Document Cover Sheets and logging of incoming and outgolng correspondence and telephone conversations. In addition to the issues covered in these procedures, the following guidelines apply:

- Public access to HEDR work. All meetings with HEDR staff and TSP members, whether one-on-one or involving a TSP subcommittee, are open to the public at the discretion of the TSP. Coples of material presented at TSP meetings are provided to each TSP member and made avallable to the public as specified In TSP Directive 89-6. Members of the public or groups can visit HEDR staff or view work in progress at the Laboratory by making prior arrangements through Battelle Public Relations and Communications. 
- Access to HEDR staff by legal representatives. Requests for Irformation or interviews for use in legal actions are coordinated and approved through the HEDR Project Manager and Battelle's legal staff. Staff recelving subpoenas or other legal summons should notffy Battelle Legal immediately.

- Communtcations with DOE and CDC. Communications between Battelle and DOE and Battelle and CDC concerning contractual or other matters are made through the HEDR Project Office.

- Project materials. All written HEDR communications with the TSP concerning plans. data, conclusions, status reports, and other similar project information are limited to material that has been revlewed and cleared through Battelle. Procedures HEDR-TP-5 (HEDR Peer Review) and HEDR-TP-6 (HEDR Review Process) apply in these cases. HEDR reports will follow the format provided in Appendix F. Letter reports contain, as a minimum, a cover letter attached to the information being transmutted. Both types of reports are cleared before transmittal to the TSP for review.
- Proposals to the TSP. Any proposals to the TSP follow the format specified in TSP Directtve 88-1. (This does not include task plans. which follow the format in TSP Directive 90-1.)

- Outside requests for information. Verbal and written requests from external sources other than the TSP, HEDR contractors, and the Fred Hutchinson Cancer Research Center are forwarded to the Project Office. Media or public requests for information are directed to HEDR staff who support TSP Communications or to the TSP Communications St.bcommittee.

\subsection{PEER REVIEW}

The HEDR Project organization includes a peer review function (Figure 3.1) responsible for planning, providing, and following up major, independent reviews of project plans, performance status, and deliverables. These reviews are conducted in accordance with Battelle guidelines, the HEDR peer review protocols, and procedure TP-5. Peer Review. Results of reviews are documented and, where necessary, tracked to closure: 


\subsection{ADMINISTRATIVE SYSTEMS AND CONTROLS}

The following sections describe the admintstrative support systems and controls that will be used to facilltate project planning and control.

\subsection{SECURITY}

The security requirements for the HEDR Project are in accordance with documented PNL security requirements. The process for identifying, searching for, retrleving, evaluating, declassifying, and makding Hanfordoriginated documents avallable to project staff and the public are described in Information Resources Task Management Plan. PNL-7719 HEDR, May 1991.

\subsection{HIEALTH AND SAFETY}

The health and safety requirements for the HEDR Project are in accordance with PNL documented requirements and the Environmental, Safety and Health Plan for the Laboratory Programs Directorate.

\subsection{PERSONNEL}

Project Office staff are assigned to the Office of Hanford Environment. Other staff are provided on a matrix basis from other technical centers of functional organizations within PNL. Figure 3.1 showed an organization chart of HEDR tasks; Table 5.1 shows the reporting organizations of HEDR task members. Task and subtask leaders are considered key staff; their support to the project is negotiated with their line management. The Project Manager provides evaluations of task and subtask leader performance on project assignments to their respective line managers, as input required for staff development reviews in acccordance with PNL documented requirements.

\subsection{LEGAL AND CONTRACTS}

Legal and contract staff provide support to ensure that work can be performed without undue disruption and that Battelle's integrity and reputation are not compromised.

Battelle's openness policy, which allows public access to HEDR technical staff and work. carries with it an obligation to maintain equity among plaintuffs and defendants of lawsuits Involving DOE and its contractors as well as organizations and individuals representing the public's interest in the information generated by the project.

\subsubsection{Legal}

Battelle's legal staff provides counsel and support as needed to review issues with legal implications and respond to legal questions. Issues Involving HEDR staff or subcontractor actions with potential legal implications are reviewed prior to implementation. Policles are established to preclude unnecessary concerns of the DOE, CDC, the TSP, or the public about Battelle's involvement or how legal situations are handled (e.g., staff interactions with litigants). Polictes regarding involvement of HEDR staff or subcontractors with ongoing lawsuits related to Hanford operations, elther with plaintiffs or defendants, have been implemented to preclude misunderstandings or conflicts of interest and maintain public confidence (e.g., not providing expert testimony for prosecuting or defense attorneys.)

\subsubsection{Contracts}

Battelle contract services staff established and maintains the legal and contractual lialson with DOE and CDC. The Project Manager, the Contracting Officer, and the financial representative perform contractrelated activities to effectively and efficiently perform and complete the project. Because of the unique arrangement between $\mathrm{CDC}$ and the TSP for directing the work of the project, the 
TABLE B.1. Battelle Organization Responsibility for HEDR Activities

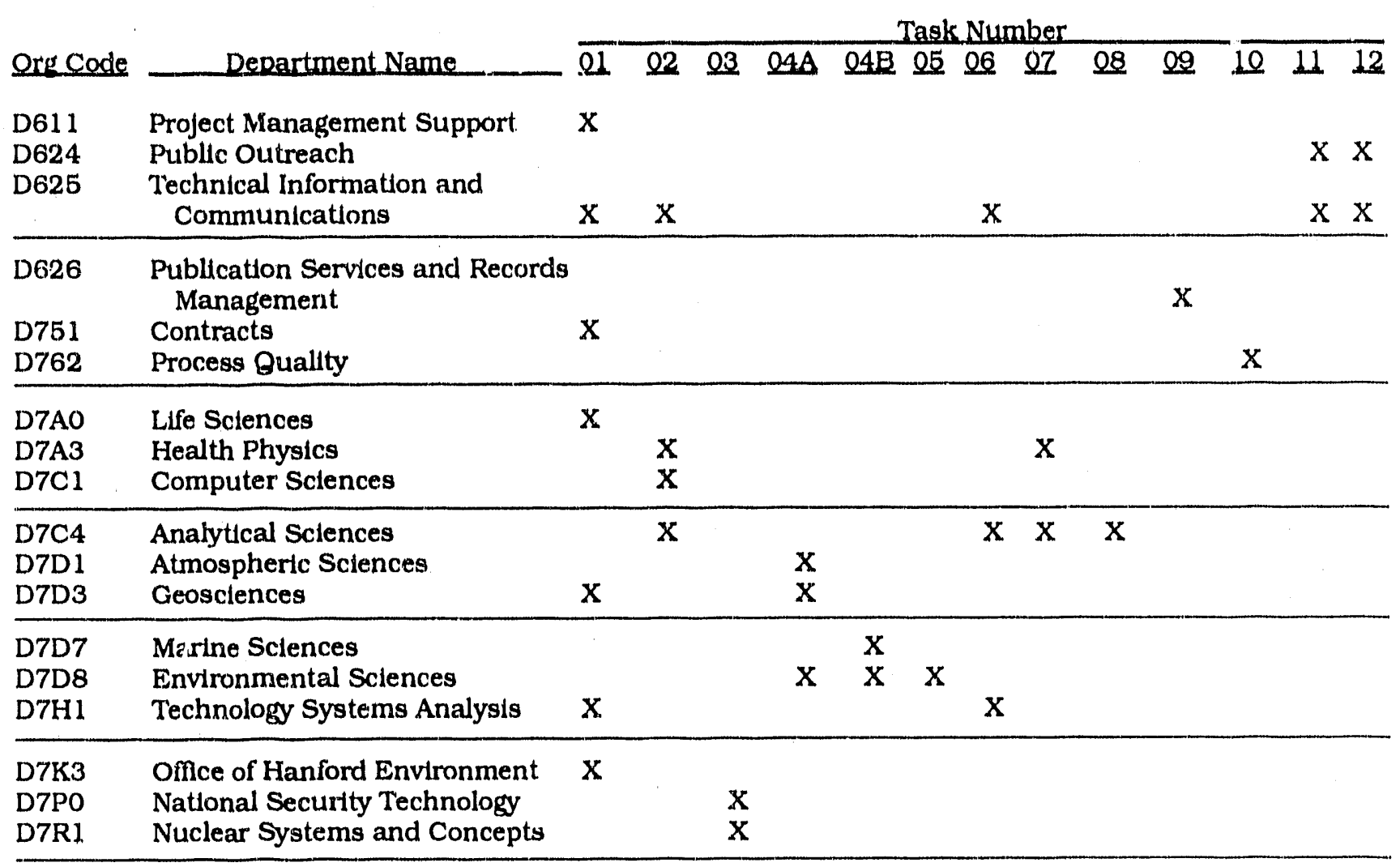

Task Number Key:

Task 01 Project Management

Task 02 Technical Integration

Task 03 Source Terms

Task 04A Atmospheric Transport

Task 04B Columbia River Transport

Task 05 Environmental Monttoring Data

Task 06 Demography, Food Consumption, and Agriculture

Contracting Officer maintains the contractual relationship with CDC and the Project Manager maintains the technical relationship with the TSP. They work together to ensure that the scope, cost, and schedule requirements of the contract are met or appropriately modified in a tirnely manner.

\subsection{PROCUREMENT}

Procurement of materlals, equipment, and services needed to accomplish technical and/ or project objectives are included in the project budget. Services may be provided by organtzations such as other Hanford contractors and
Task 07 Environmental Pathways and Dose Estimates Task 08 Statistics

Task 09 Records Management

Task 10 Quality Assurance

Task 11 Information Resources

Task 12 TSP Communication Support private vendors. Procurement activities are conducted in accordance with PNL documented procurement procedures.

\subsection{DATABASE MANAGEMENT}

Computerized databases are developed, maintained, and made avallable to management, Task Leaders, peer reviewers, the TSP, and the public as part of project objectives related to open communications, quality and credible science, and effective and efficient achlevement of technical goals. HEDR databases can be categorized as administrative, technical, and communications. Many of 
these databases are used by Task Leaders and the Project Manager to ensure that technical work is properly performed, controlled. and documented, and to meet quality assurance requirements and objectives. Some database information is also used to prepare HEDR monthly reports, which are submitted to the TSP and made available to the public.

\subsubsection{Administrative Databases}

Administrative databases include those for project records, action/milestone tracking. document clearance tracking, flle transfers, records management, transfers to the Public Reading Room, transfers to the Battelle Records Center, subcontracts status, cost management, invoice management, and those maintained by HEDR Information Resources staff of Hanford-originated historical documents.

The historical documents database is described here because of its key importance to the project and because it is created and maintained in accordance with specific procedures. Information Resources staff identify, search for, retrieve, declassify (if necessary). make avallable, and annotate Hanfordoriginated documents in a database called tise HEDR Information Resources Tracking System (HIRTS). HIRTS contains bibliographic information on each document such as its number, author, titie, date, document form, location, public availability, and names of people who requested coples. The documents are used by technical HEDR staff and TSP memivers in dose reconstruction work. Detalls of how this database is created and maintained are found in the Information Resources Task Management Plan, PNL-7719 HEDR, May 1991.

\subsubsection{Technical Databases}

Technical databases include annotated bibliographies of Hanford-generated documents, pathways parametric values, dose conversion values, dose estimates, demographic information, agricultural information, source terms, meteorologic information. groundwater information, surface-water information, and intermediate calculations results. Various technical databases include the QUEST database, which contains healthphysics-related journal titles; CHERNOLIT. which contains Chernobyl-related information; the Source Term Bibliographic Database: a meteorological database comprised of meteorological and topographic data files; the Environmental Monitoring Document Database and individual environmental monitoring databases on surface water, fish and vegetation: and databases of demographic, food consumption, and milk production/distribution information. Databases/files of calculated information such as time-and location-spectfic integrated air concentrations and integrated depositions, time and location concentrations of nuclides in rtver water, and other intermedlate numerical databases/files, will also be maintained in accordance with the Data Management Plan (being developed).

\subsubsection{Communications Databases}

Communications-related databases include titles of presentations to the TSP. HEDR documents, open literature publications, and public presentations.

\subsection{PROPERTY MANAGEMENT}

The Project Office acquires and manages various property items to effectively perform technical, project planning and control, and administrative work. These items include furniture, computer equipment., and audio/ visual and telecommunications equipment.

In addition to desktop IBM and Macintosh computers for daily work, the project also maintains an IBM/PC with an ARC/INFO capability (a Geographic Information System) for managing and displaying project temporal and spacial information such as demographics, agricultural practices, cartographic information, dose estimates, meteorological data. dispersion and deposition data, environmental contamination, river-water concentrations, and groundwater migration patterns.

The project has recently acquired a SUN4 / RISC computer system and a supporting 
SPARC2 work station to support environmental transport, pathway, and dose estimating calculations and data storage requirements. Acquisition of additional computer storage capability is anticipated in FY 1992 or 1993 to support final dose estimations. An opticaldisk-based records management system and enhanced, portable, color projection capabillties for the Geographic Information System are also anticipated in FY 1992. No other major property acquisitions are planned through FY 1993. The dose estimating turn-over package (hardware and software) will be defined in FY 1993 for purchase in FY 1994 or 1995.

All acquired property is inventoried and tagged in accordance with DOE and Battelle requirements and audits are performed regularly to ensure proper control.

\subsection{SUBCONTRACTOR CONTROLS}

The subcontract specialist assigned to the project controls the issuance of subcontracts, negotlates scope and cost in cooperation with a technical administrator, reviews and approves involces, and ensures that project deliverables are obtained before the subcontract is closed out. Subcontract activities are conducted in accordance with PNL documented subcontracting procedures.

\subsection{COMMUTMENT CONTROL}

The Commitment Control Log for the HEDR Project is maintained by the Project Office. Action items and agreements are documented and tracked. Actions and agreements are documented by item, with an individual assigned responsibility for completion by a specific due date. Samples of input/change and report forms are shown in Appendix G. 


\section{APPENDIX A}

PROJECT WORK BREAKDOWN STRUCTURE AND TASKS 


\section{APPENDIX A}

\section{PROJECT WORK BREAKDOWN STRUCTURE AND TASKS}

1 Project Management

1.1 Project planning and control

1.1.1 Work breakdown structure/dictionary

1.1.2 Network development and control

1.1.3 Planning guidance

1.1.4 Correcttve action planning

1.1.5 Project Management Information System

1.1.6 Project management reports

1.1.6.1 HEDR monthly report

1.1.6.2 Financial reports

1.1.6.3 Scope/cost/schedule reports

1.1.6.4 Battelle management reports

1.2 Project documents

1.2.1 Document hierarchy

1.2.2 Project ptan (deleted)

1.2.3 Project management plan

1.2.4 Task plans

1.2.5 Quality assurance plan

1.2.6 Other HEDR documents

1.3 Project administration

1.3.1 TSP lialson and response to requests

1.3.2 CDC liaison

1.3.3 Task management and coordination

1.3.4 Staff development

1.3.5 Battelle rnanagement liaison

1.3.6 Project computer administration

1.4 Records control

1.4.1 Commitment tracking

1.4.2 Document clearances

1.4.3 Records transfer

1.4.4 Records database management

1.5 Peer review

1.5.1 Plans review

1.5.2 Presentation review

1.5.3 Document review

1.5.4 Technical review

1.6 Subcontract administration

1.6.1 TSP contracts

1.6.2 Nattve American contracts

1.6.3 Consultants

1.7 Project communications support

1.7.1 Communication planning

1.7.2 Communications reviews

Communications revlews
1.7.2.1 Finalize Phase I reports

1.7.3 Meeting/workshop support 
1.7.4 Project communications products

1.7.5 Response to public requests

2 Project Technical Integration

2.1 Technical sensitivity/uncertainty analysis

2.2 Technical coordination and integration

2.2.1 Planning Integration

2.2.2 Public communication

2.2.3 TSP coordination

2.2.4 Native American Working Group lialson

2.2.5 Data integration

2.2.6 Review and interpretation of technical results

2.3 Population dose model requirements

2.3.1 Code design specifications

2.3.2 Dominant radionuclides

2.3.3 Dominant pathways

2.3.4 Characteristics of population groups

2.4 Individual dose model requirernents

2.4.1 Code design specifications

2.4.2 Dominant radionuclides

2.4.3 Dominant pathways

2.4.4 Characteristics of individuals

2.5 Code verification/validation

2.5.1 IAEA model intercomparison

2.5.2 Model/code veriflcation and validation plan

2.6 HTDS coordination

2.7 Data management oversight

2.7.1 Data management plan

2.8 Technical planning, control and reporting

2.8.1 Project planning/task planning

2.8.2 Meetings

2.8.2.1 TSP/public meetings

2.8.2.2 Project meetings

2.8.3 Documentation, reporting and publications

2,8.4 Quality objectives, achicvi:ments and verification

2.8.5 Project integration/Interactions

3 Source Terms

3.1 Release data avallabllity and review

3.1.1 Data on releases to air

3.1.2 Data on releases to water.

3.2 Releases to air

3.2.1 Early todine releases from separations facilities (1944-1947)

3.2.2 Late lodine releases to air (1947-present)

3.2.3 Releases from separations areas (200 areas)

3.2.3.1 Releases from separations facilities

3.2.3.1.1 Releases from 1944-1957

3.2.3.1.2 Releases from 1957-1990

3.2.3.2 Releases from other separations areas

3.2.4 Releases from reactor areas (100 areas)

3.2.5 Releases from laboratory/test reactor areas (300/400 areas)

3.3 Hanford Historical Releases 
3.4 Waterborne releases

3.4.1 Waterborne releases (1944-1957)

3.4.2 All waterborne releases

3.4.3 Groundwater releases

3.5 Release model development (day time)

3.5.1 Iodine release model (input to pathways and dose model) - air

3.5.2 Other nuclide release model

3.5.2.1 Air

3.5.2.2 Water

3.5.3 Model validation and verification

3.6 Technical planning, control and reporting

3.6.1 Project planning/task planning

3.6.2 Meetings

3.6.2.1 TSP/public meetings

3.6.2.2 Project meetings

3.6.3 Documentation, reporting and publications

3.6.4 Quality objectives, achievements and verification

3.6.5 Project integration/Interactions

4 Environmental Transport

4.1 Atmospheric transport

4.1.1 Model restructuring and revision

4.1.1.1 Wind (uncertainty)

4.1.1.2 Stability (spatial variation and uncertainty)

4.1.1.3 Mixdng layer (calculation, spatial vartation, uncertainty)

4.1.1.4 Precipitation (uncertainty, spatial variation)

4.1.1.5 Temperature (uncertainty)

4.1.1.6 Wind profiles (uncertainty)

4.1.1.7 Surface roughness (find data)

4.1.1.8 Characteristic turbulence velocity (uncertainty)

4.1.1.9 Diffusion coefficients (revise, uncertainty)

4.1.1.10 Deposition (resistance model, spatial variation, uncertainty)

4.1.1.11 Washout (uncertainty and spatial variation)

4.1.1.12 Plume rise (uncertainty)

4.1.1.13 Transport at center of mass

4.1.1.14 Mass balance

4.1.1.15 Multiple sources

4.1.1.16 Polar grld (close-in workers)

4.1.1.17 Input/output modification

4.1.2 Wind field modeling

4.1.2.1 Literature search and model evaluation

4.1.2.2 Tests

4.1.2.3 Implementation

4.1.3 Model sensitivity

4.1.3.1 Release time

4.1.3.2 Wind data (resolution)

4.1.3.3 Temperature (plume rise)

4.1.3.4 Precipitation

4.1.3.5 Mixing layer thickness

4.1.3.6 Surface roughness

4.1.3.7 Duffusion parameterization

4.1.3.8 Deposition parameterization and deposition velocity 
4.1.4 Meteorological database

4.1.4.1 Hourly data (wind, stabllity, precipitation, and temperature)

4.1.4.2 Dally data (precipitation)

4.1.4.3 Surface roughness

4.1.5 Model validation

4.1.5.1 Validation data sets

4.1.5.2 Detalled validation plan

4.1.5.3 Validation model runs

4.1.6 Final documentation

4.1.6.1 Database

4.1.6.2 Computer model

4.1.7 Calculations

4.1.7.1 HTDS

4.1.7.2 Chronic releases

4.1.7.3 Spectal studies (e.g. "green run")

4.1.7.3.1 Database preparation

4.1.7.3.2 Model modification

4.1.7.3.3 Model documentation

4.1.8 Special studies

4.1.7.3.4 Calculation

4.1.8.1 Resuspension

4.1.8.2 Thunderstorms

4.1.8.3 Alr chemistry of $1-131$

4.2 Ground-water transport

4.2.1 Well data analysis

4.2.1.1 On-site well data evaluation

4.2.1.2 Off-site well data evaluation

4.2.2 Air deposition to groundwater transfer

4.2.3 Off-site migration

4.2.3.1 Effects on off-site wells

4.2.3.2 Effects on the rtver

4.3 Surface-water transport

4.3.1 Monitoring data evaluation

4.3.1.1 Data/information assembly

4.3.1.2 Develop bibliography

4.3.1.3 Data quality evaluation

4.3.1.4 Data gaps reconciliation (time/location)

4.3.2 Conceptual modeling

4.3.2.1 Basic river processes

4.3.2.2 Significant locations/tirnes

4.3.2.3 Numerical modeling approach

4.3.3 Calculation of concentrations

4.3.3.1 Inttial screening calculations

4.3.3.2 Concentrations at points of interest

4.3.3.3 Database for dose model

4.4 Technical planning, control and reporting

4.4.1 Project planning/task planning

4.4.2 Meetings

4.4.2.1 TSP/public meetings

4.4.2.2 Project meetings

4.4.3 Documentation, reporting and publications 
4.4.4 Quality objectives, achievements and verification

4.4.5 Project integration/Interactions

5 Environmental Monitoring Data

5.1 Data avallability and review

5.1.1 Document search, review, and collection

5.1.2 Document inventory and database entry

5.1.3 Data evaluation and maintenance

5.2. Terrestrial data (vegetation, crops, food stuff and soil)

5.2.1 Document review and inventory

5.2.2 Data extraction and database entry

5.2.3 Sampling methods review and evaluation

5.2.4 Analytical methods review and evaluation

5.2.5 Blases and uncertainties

5.2.6 Hanford contributions

5.3 Surface-water data (Columbla River, sediments, aquatic biota)

5.3.1 Document review and inventory

5.3.2 Data extraction and database entry

5.3.3 Sampling methods review and evaluation

5.3.4 Analytical methods review and evaluation

5.3.5 Blases and uncertainties

5.3.6 Hanford contributions

$5.4 \quad$ Air data

5.4.1 Document revlew and inventory

5.4.2 Data extraction and database entry

5.4.3 Sampling methods review and evaluation

5.4.4 Analytical methods review and evaluation

5.4.5 Blases and uncertainties

5.4.6 Hanford contributions

5.5 Ground.water data

5.5.1 Document review and inventory

5.5.2 Data extraction and database entry

5.5.3 Sampling methods review and evaluation

5.5.4 Analytical methods review and evaluation

5.5.5 Blases and uncertainties

5.5.6 Hanford contributions

5.6 Technical planning, control and reporting

5.6.1 Project planning/task planning

5.6.2 Meetings

5.6.2.1 TSP/public meetings

5.6.2.2 Project rneetings

5.6.3 Documentation, reporting and publications

5.6.4 Quality objectives, achievements and verification

5.6.5 Project integration/interactions

6 Demographics, Agriculture, Food Habits

6.1 Demographlcs

6.1.1 General population

6.1.1.1 Phase I Area

6.1.1.2 Extension of geographlc study area

6.1.1.3 Duration of residence/migration

6.1.2 Special populations 


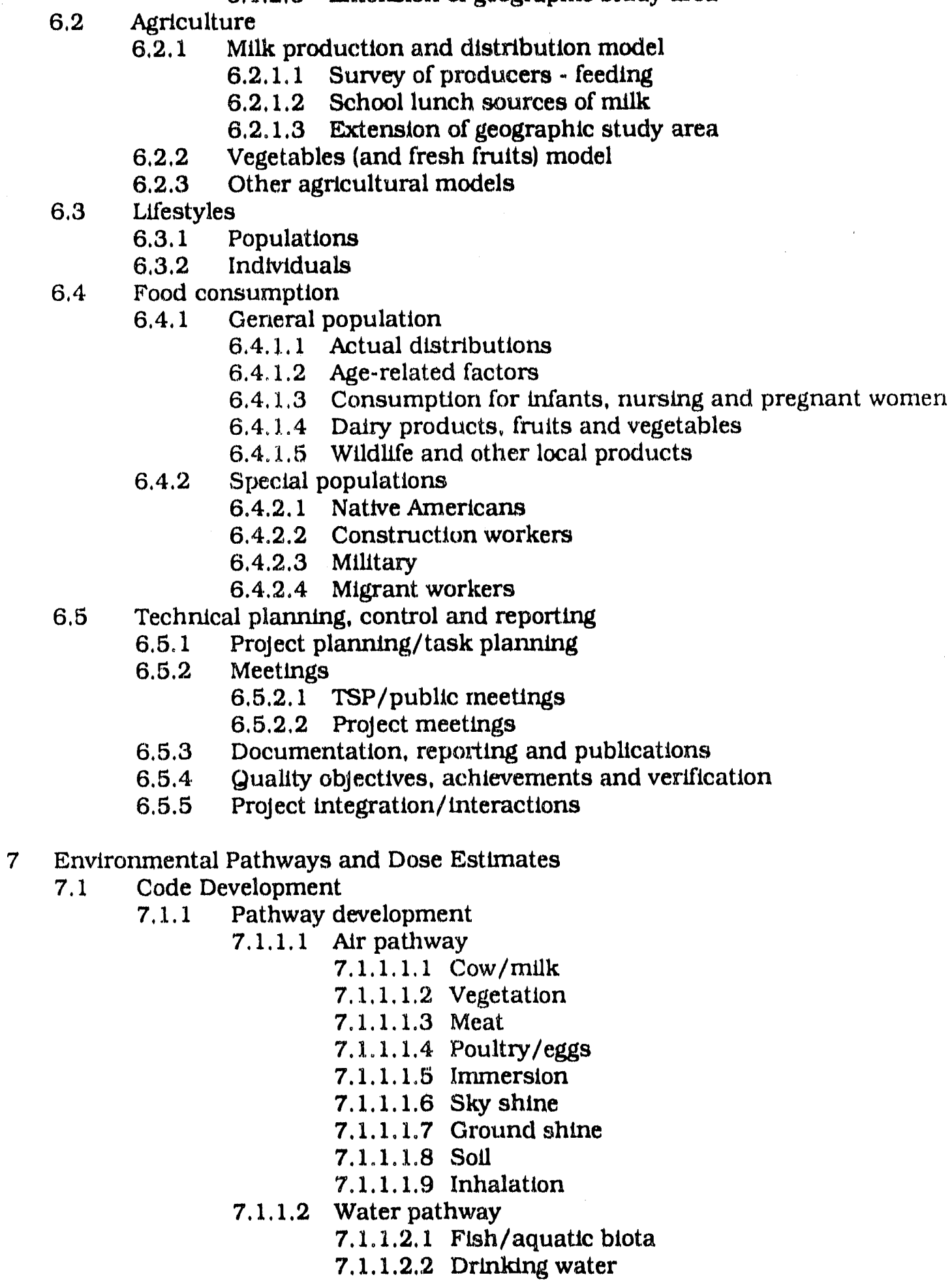

7 Environmental Pathways and Dose Estimates

7.1 Code Development

7.1.1 Pathway development

7.1.1.1 Alr pathway

7.1.1.1.1 Cow/milk

7.1.1.1.2 Vegetation

7.1.1.1.3 Meat

7.1.1.1.4 Poultry/eggs

7.1.1.1.5 Immersion

7.1.1.1.6 Sky shine

7.1.1.1.7 Ground shine

7.1.1.1.8 Soll

7.1.1.1.9 Inhalation

7.1.1.2 Water pathway

7.1.1.2.1 Fish/aquatic blota

7.1.1.2.2 Drinking water 


\author{
7.1.1.2.3 Immersion \\ 7.1.1.2.4 Boating/flshing/shoreline \\ 7.1 .2 Code structuring \\ 7.1.2.1 Correlations/demodularization \\ 7.1.2.2 Dynamics \\ 7.1.2.3 Data handling \\ 7.1.3 Coding implementation \\ 7.1.3.1 Writing code \\ 7.1.3.2 Veriflcation/bench marking \\ 7,1.3.3 Quallty assurance \\ 7.1.4 Code documentation \\ 7.1.4.1 Theory manuals \\ 7.1.4.2 Users manuals \\ 7.1.4.3 Dose estimation turnover package \\ 7.1.5 Model/code valldation \\ 7.1.5.1 Monitoring data \\ 7.1.5.2 Bloassay data \\ 7.2 Dose Calculations \\ 7.2.1 Population group doses \\ 7.2.1.1 Native American Tribes Doses \\ 7.2.1.1.1 Yakdma \\ 7.2 .1 .1 .2 Umatllla \\ 7.2.1.1.3 Nez Perce \\ 7.2.1.1.4 Colville \\ 7.2.1.1.5 Coeur d'Alene \\ $7,2,1,1.6$ Kallspel \\ 7.2.1.1.7 Warm Springs \\ 7.2.1.1.8 Spokane \\ 7.2.1.2 Milltary Doses \\ 7.2.1.3 Migrant Doses \\ 7.2.1.4 Construction Worker Doses \\ 7.2 .2 Individual doses \\ 7.2.2.1 HTDS Doses \\ 7.2.2.1.1 Feaslbility study doses \\ 7.2 .2 .1 .2 Full study doses \\ 7.2.2.2 Individuals on request \\ 7.2.3 Nuclides of interest \\ 7.2.3.1 Iodine Doses \\ 7.2.3.2 Ruthenlum Doses \\ 7.2.3.3 Plutonlum Doses \\ 7.2.3.4 Other nuclldes \\ 7.2.4 Pathways of interest \\ 7.2.4.1 Alr pathway doses \\ 7.2.4.2 River pathway doses \\ 7.2.4.3 Groundwater pathway doses \\ 7.2.4.4 River irrigation doses \\ 7.2.4.5 Cistern doses \\ 7.2.4.6 Raln-out doses \\ 7.2.4.7 Other pathways of Interest \\ 7.2.5 Special release events \\ 7.2.5.1 "Green run doses
}


7.2.5.2 Fuel fallures

7.2.5.3 "Hot particles"

7.3 Model parameter development

7.3.1 Dose factors

7.3.2 Transfer factors

7.3.3 Accumulation Factors

7.4 Technical planning, control and reporting

7.4.1 Project planning/task planining

7.4.2 Meetings

7.4.2.1 TSP/public meetings

7.4.2.2 Project meetings

7.4.3 Documentation, reporting and publications

7.4.4 Quality objectives, achlevements and verification

7.4.5 Project integration/Interactions

8 Statistics support

8.1 Technical Integration (Task 02)

8.1.1 Restructuring pathway dose codes

8.1.1.1 Alr

8.1.1.2 Water

8.1.2 Developing data management within pathway dose codes

8.1.3 Revlew task plans and data quallty objectives

8.1.4 Review products

8.1.5 Statistics publications

8.2 Source Terms (Task 03)

8.2.1 Revlew task plan and data quality objecttves

8.2.2 Review products

8.2.3 Sensitivity/uncertainty analysis and data management

8.2.4 Review/evaluate/assist with data and calculations

8.3 Environmental transport (Task 04)

8.3.1 Review task plan and data quality objectives

8.3.2 Review products

8.3.3 Sensitivity/uncertainty analysis and data management

8.3.4 Review/evaluate/assist with data and calculations

8.4 Environmental monitoring data (Task 05)

8.4.1 Revlew task plan and data quality objectives

8.4.2 Review products

8.4.3 Review/evaluate/assist with data and calculations

8.4.4 Validation of alr disperston model

8.5 Demographics, agriculture, food habits (Task 06)

8.5.1 Revlew task plan and data quality objectives

8.5.2 Review products

8.5.3 Review/evaluate/assist with data and calculations

8.5.4 Sensittvity/uncertainty analysis and data management

8.6 Enwironmental pathways and dose estimates (Task 07)

8.6.1 Review task plan and data quality objectives

8.6.2 Review products

8.6.3 Sensitivity/uncertainty analyses and data management.

8.7 Technical planning, control and reporting

8.7.1 Project planning/task planning

8.7.2 Meetings 


\subsubsection{TSP/public meetings}

8.7.2.2 Project nueetings

8.7.3 Documentation, reporting and publications

8.7.4 Quality objectives, achievements and verification

8.7.5 Project Integration/interactions

9 Records Managernent

9.1 Battelle records management

9.2 DOE Fleld Office, Richland, Public Reading Room

9.3 Task planning, control and reporting

9.3.1 Project planning/task planning

9.3.2 Project meetings

9.3.3 Documentation, reporting and publications

9.3.4 Quality objectives, achievements and verification

10 Quality Assurance

10.1 Quality assurance procedures

10.2 Data quallty objectives

10.3 Quality improvement

10.4 Quality verffication activities

10.5 Task planning, control and reporting

10.5.1 Project planning/task planning

10.5.2 Project meetings

10.5.3 Documentation, reporting and publications

10.5.4 Project integration/Interaction

11 Information Resources

11.1 Document declassification

11.2 Resource identification and avallablity

11.3 Task planning, control and reporting

11.3.1 Project planning/task planning

11.3.2 Project meetings

11.3.3 Documentation, reporting and publications

11.3.4 Quality objectives, achlevements and verification

12 TSP Communications Support

1.2.1 Public outreach support

12.1.1 Video

12.1.1.1 Production

12.1.1.2 Distribution

12.1.2 Posters

12.1.2.1 Production

12.1,2.2 Distribution

12.1.3 Document accessibility

12.2 Communication Assessment

12.2.1 Focus groups

12.2 .2 Individuals

12.3 Audlence analysis

12.3.1 Public meeting attendance

12.3.2 Clippings

12.4 Presentation coordination

12.5 TSF meeting/workshop/symposla support 
12.6 TSP materlals support

12.6.1 Material supply

12.6.2 Revlews

12.6.3 Editing/writing

12.6.4 Document retrieval

12.7 Task planning, control and reporting

12.7.1 Project planning/task planning

12.7.2 Meetings

12.7.2.1 TSP/public meetings

12.7.2.1 Project meetings

12.7.3 Documentation, reporting and publications

12.7.4 Quality objectives, achievements and verification 


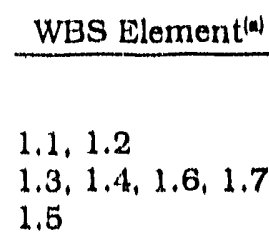

\section{8}

$2.1,2.2,2.6,2.7$

$2.3,2.4,2.5$

\section{6 \\ 3.2 \\ 3.4 \\ 3.5 \\ 3.3 \\ 3.1}

\section{4}

$4.1 .1,4.1 .2$,

$4.1 .3,4.1 .5,4.1 .6$

4.1 .4

4.1 .7

\section{4}

4.3

5.2

5.1

5.3

5.4

6.5

6.4

6.2

$6.1,6.3$

6.4 .2

7.4

7.1

7.3

7.1 .5

7.2
Subtask

Task Manager

01 Project Manugement

0101 Project Planning and Control

0103 Project Administration

0104 Project Peer Review

02 Techniond integration

0201 Technical Planning, Control, and Reporting

0204 Project Technical Coordination and Analysis

0205 Pathways and Dose Model Requitrements

03 Source Terms

0301 Technical Planning, Control, and Reporting

0303 Radioacttve Releases to Air

0304 Radioactive Releases to Water

0305 Release Model Development, Vertflcation, and Validation

0306 Hanford Historlcal Releases

0307 Radioactive Release Data Avallability and Review

04A Atmowpheric Transport

0401 Technical Planning, Control, and Reporting

0402 Atmospheric Model Development and Evaluation

0405 Atmospherlc Model Database

0406 Atmospheric Model Calculations

04B Columbia River Transport

0401 Technical Planning, Control, and Reporting

0404 Surface-Water Transport

O5 Enviranmental Monitoring Data

0501 Technical Planning, Control, and Reporting

0502 Terrestrial Monitoring Data

0503 Environmental Monitoring Data Avallabillty and Review

0504 Surface-Water Monltoring Data

0505 Air Monitoring Data

06 Demography, Food Consumption, and Agriculture

0601 Technical Planning, Control, and Reporting

0602 Food Consumption

0603 Mllk and Other Food Model Development

0604 Demographics

0605 Nattve American Data

07

Environmental Pathwaye and Dose Estimates

TA Ikenberry
DB Shipler

BA Napier

CM Heeb

JV Ramsdell

WH Waltors

RL Dirkes

DM Beck
0701 Technical Planning, Control, and Reporting

0702 Pathways and Dose Code Development and Documentation 0703 Pathways and Dose Model Parameter Development

0704 Pathways and Dose Model/Code Veriflcation and Validation 0705 Dose Calculations 
TABLE A.1. (contd)

WBS Element(w)

\section{7}

$8.2,8.3,8.4$

$8.5,8.6$

8.1

9.3

$9.1,9.2$

10.5

$10.1,10.2,10.3$

10.4

11.3

11.1

11.2

12.7

12.1

$12.2,12.3$

$12.4,12.5,12.6$

$7.1,4.3$
Task

08

atistic

0801 Technical Planning. Control, and Reporting

0802 Statistics Support for Project Technical Task Work

0803 Analysis of Model Reliabllity

09 Records Management

0901 Technical Planining, Control, and Reporting

0902 Project Records Management

10 Quality Assurnnce

1001 Technical Planning, Control, and Reporting

1002 Quality Assurance Program Development

1003 Quallty Assurance Verification

11

\section{Information Resources}

1101 Technical Planning, Control, and Report

1102 Hanford Document Declassiflcation

1103 Hanford Information Resources Identiflcation and Search

12 TSP Communication Support

1201 Technical Planning, Control, and Reporting

1202 TSP Public Outreach Support

1203 Communications Assessment Rescarch

1204 TSP Meeting and Materials Support.

1206 Dose Estimating Turnover Package
Task Manager

RO Gilbert

DL Alamia

DL, stewart

GX Harvey

GL, Harvey

(a) See Figure 2.1 for WBS element titles that correspond to these numbers. 


\section{APPENDIX B}

\section{PROJECT SUMMLARY SCHEDULE}




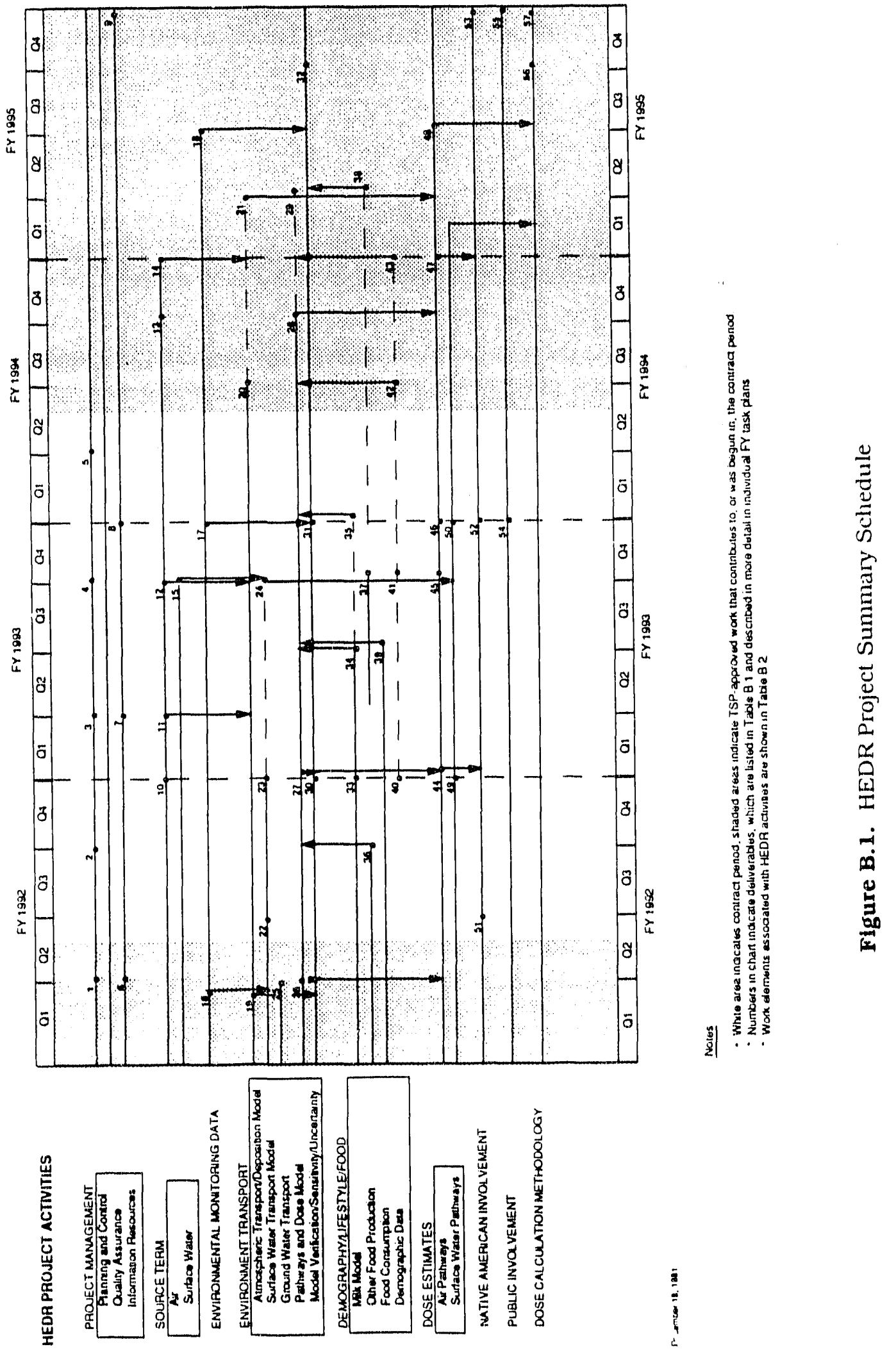

B. 1 
TABLE B.1. HEDR Project Deliverables (Those that are shaded are before or after the CDC contract period; unshaded ones are within the contract period.)

\begin{tabular}{|c|c|c|c|}
\hline PSS $($ (n) & $\begin{array}{c}\text { Task } \\
\text { Plans (b) }\end{array}$ & Description & Date \\
\hline \%: & \%1018. & 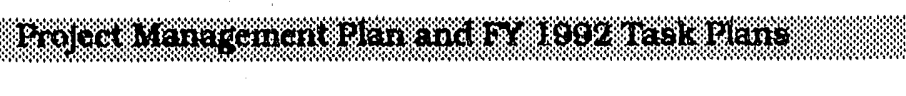 & $1.0 \% 92$ \\
\hline 2. & $0101 \mathrm{D}$ & FY 1992 Task Plans, Mid-Year Review & $6 / 30 / 92$ \\
\hline 3. & $0101 \mathrm{G}$ & FY 1993 Task Plans & $1 / 01 / 93$ \\
\hline 4. & $0101 \mathrm{E}$ & FY 1993 Task Plans, Mid-Year Review & $6 / 30 / 93$ \\
\hline 5. & 01011 & Project Final Report & $12 / 31 / 93$ \\
\hline $6 \%$ & \% & 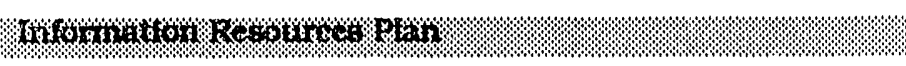 & 1\% $19192 \%$ \\
\hline 7. & $1102 \mathrm{~A}$ & Information Resources Summary Report & $1 / 01 / 93$ \\
\hline 8. & $1103 \mathrm{~B}$ & Information Resources Summary Report & $9 / 30 / 93$ \\
\hline $9 . \%$ & \%ি &  & $9.80 \% 5 \%$ \\
\hline 10. & -- & Key Nuclides Decision (TSP) $)^{(c)}$ & $9 / 30 / 92$ \\
\hline 11. & $0303 \mathrm{C}$ & I-131 Source Term (1944-1991) & $12 / 31 / 92$ \\
\hline 12. & 0303D & Key Radionuclides Report, Alr & $6 / 30 / 93$ \\
\hline \%). & \%ి: & 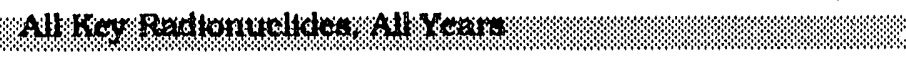 & $6 \%$ \%०/94\% \\
\hline . 4 4: & :. &  & $9 / 30 \% 9 \%$ \\
\hline 15. & 0304B & Reactor Releases to Surface Water (1944-1991) & $6 / 30 / 93$ \\
\hline 17. & $0502 \mathrm{C}$ & Monitoring Data Report & $9 / 30 / 93$ \\
\hline 16: & $0404 \%$ & eormlor r. & $2.101 \% 2 \%$ \\
\hline 18\% & ;: & 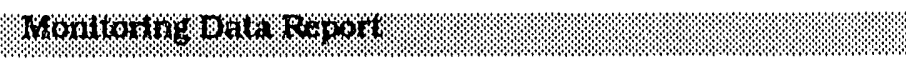 & $3 / 31 / 95 \%$ \\
\hline $19 \%$ & 04028 & 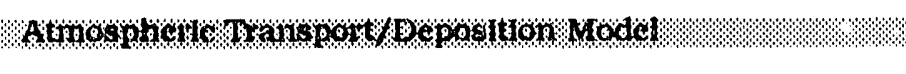 & $2 \% 01 / 92 \%$ \\
\hline 20 . & :.: &  & $3 \% 1 \% 9$ \\
\hline 21: & : & 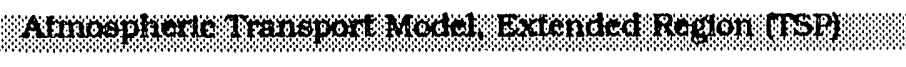 & $12 \% 3 \% 9 \%$ \\
\hline 22. & -- & Surface Water Dose Monitoring/Modeling Decision (TSP) & $3 / 31 / 92$ \\
\hline 23. & $\cdots$ & Surface Water Extended Region Decision & $9 / 30 / 92$ \\
\hline 24. & $0404 \mathrm{C}$ & Surface Water Transport Model & $6 / 30 / 93$ \\
\hline 25\% & $0403 \%$ & 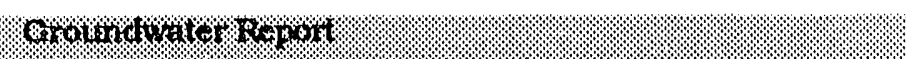 & $1107 \% 92$ \\
\hline
\end{tabular}


TABLE B.1. (contd)

\begin{tabular}{|c|c|c|c|}
\hline $\mathrm{PSS}^{(a)}$ & $\begin{array}{l}\text { Task } \\
\text { Plans } \\
\end{array}$ & Description & Date \\
\hline $26 \%$ & 08024 &  & 2104192 . \\
\hline 27. & 0702B & Population Dose Model & $9 / 30 / 92$ \\
\hline 28. & ?.: & 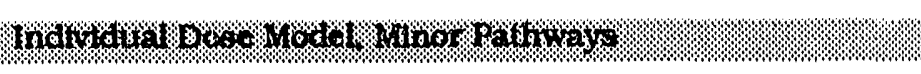 & $6 \% \% \%$ \\
\hline 29. & \%ি. & 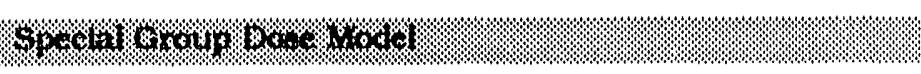 & 1\%\%\%? \\
\hline 30. & $\cdots$ & Verfication/Validation Plan Decision (TSP) & $9 / 30 / 92$ \\
\hline 31. & 08038 & Model Veriflcation/Sensittvity/Uncertainty Report & $9 / 30 / 93$ \\
\hline $32:=$ & \% & 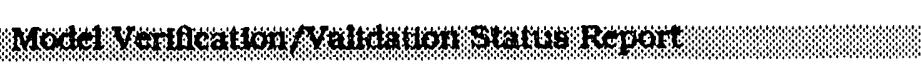 & $6730 \% 95 \%$ \\
\hline 33. & -- & Milk Model, Extended Region Decision (TSP) & $9 / 30 / 92$ \\
\hline 34. & $0603 \mathrm{D}$ & Mulk Production and Distribution Model (19 countles) & $3 / 31 / 93$ \\
\hline 35. & $0603 \mathrm{E}$ & Mulk Production and Distribution Model, Extended Reglon & $9 / 30 / 93$ \\
\hline 36. & $0603 \mathrm{C}$ & $\begin{array}{l}\text { Food Production and Distribution, Green Leafy Vegetables } \\
\text { (19 counties) }\end{array}$ & $6 / 30 / 92$ \\
\hline 37. & $\cdots$ & Food Production, Extended Region Decision (TSP) & $6 / 30 / 93$ \\
\hline 38. & ;. &  & $12.80 \% 9 \%$ \\
\hline 39. & $0602 \mathrm{C}$ & Food Consumption Report. & $3 / 31 / 93$ \\
\hline 40. & -- & Leaiy Vegetable, Extended Region Decision (TSP) & $9 / 30 / 92$ \\
\hline 41. & -- & Demographic Data, Special Groups Decision (TSP) & $6 / 30 / 93$ \\
\hline 12. & a. & 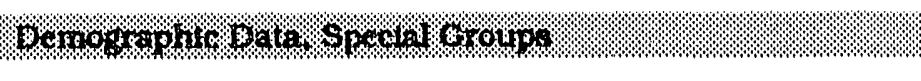 & $16 \% 8$ \\
\hline (1). & \%.. & 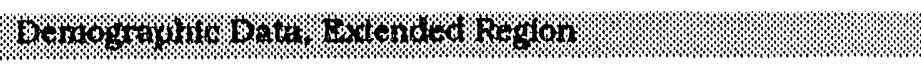 & 9130194 \\
\hline 44. & -- & $\begin{array}{l}\text { Nattve Amertcan Phase I Doses (Battelle - } \\
\text { dose calculations; TSP - report) }\end{array}$ & $9 / 30 / 92$ \\
\hline 45. & 0705A & I-131 Dosimetry Report & $6 / 30 / 93$ \\
\hline 46. & $0705 \mathrm{C}$ & Key Radionuclides Dosimetry Report, Air & $9 / 30 / 93$ \\
\hline $17 \%$ & ?ו. & 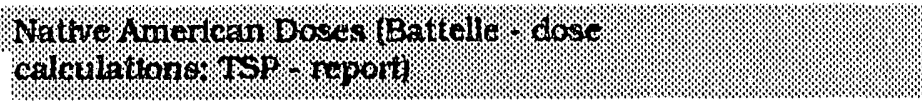 & $980 \% 94$ \\
\hline $18 \%$ & :. & 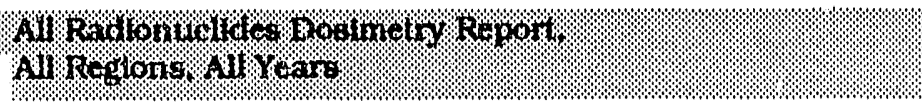 & 3. \\
\hline 49. & -- & Native American Continuing Research Plan (TSP) & $9 / 30 / 92$ \\
\hline
\end{tabular}


TABLE B.1. (contd)

\begin{tabular}{|c|c|c|c|}
\hline PSS $^{(\text {a) }}$ & $\begin{array}{l}\text { Task } \\
\text { Plans (b) }\end{array}$ & Description & Date \\
\hline 50. & $0705 B$ & Surface Water Dosimetry Report & $9 / 30 / 93$ \\
\hline 51. & -- & Native Arrerican Phase I Data Report (TSP) & $3 / 31 / 92$ \\
\hline 52. & -- & Continuing Native American Research Report (TSP) & $9 / 30 / 93$ \\
\hline 6 \% & 8 & 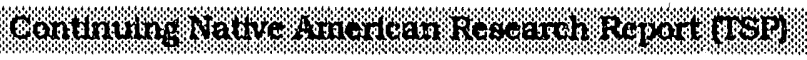 & $9 \% \%$ \\
\hline 54. & -. & Communications Report (TSP) & $9 / 30 / 93$ \\
\hline 86 & ఖ. & - & $900 \% 8$ \\
\hline 86. & $2 \%$ &  & 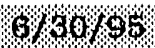 \\
\hline 57 & 2 &  & 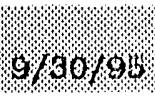 \\
\hline
\end{tabular}

(a) PSS = Dellverable number that appears in Project Summary Schedule (Figure B.1).

(b) Milestones that appear in indtvidual FY task plans.

(c) TSP = Deliverable or decision of the Technical Steering Panel. HEDR planned work is based on the assumption that all TSP decisions shown in this table result in a "yes," 1.e., that the work will be done. For example, Project Summary Schedule deliverable 22--Surface Water Dose Monitoring/Modeling Decision (TSP)--is assumed to result in the TSP directing HEDR staff to create the surface water transport model shown in Project Summary Schedule deliverable 24.

NOTES:

Assumptions associated with deliverables are described in individual FY task plans.

Dates shown are when the draft dellverables are provided to the TSP and CDC for revlew. Comments by the TSP and CDC on deliverables will be returned to BNW within one month, via the TSP. Battelle-Northwest will provide final reports one month later. 


\section{APPENDIX C}

\section{BATTELLE HIEDR SPEND PLAN}






C. 1 


\section{APPENDIX D}

OUTLINE FOR MONTHLY REPORT INPUT, BY TASK 


\section{APPENDLX D}

\section{OUTLINE FOR MONTHLY REPORT INPUT, BY TASK}

\section{Objective}

This paragraph is a concise statement of the objectives of the task.

\section{Progress (By Milestone and/or Subtask)}

This section summarizes key technical activities and significant results under the milestone to which they contribute. On work that does not contribute to a specific milestone, list it under the applicable subtask or major work element. Give enough detall to give the general public an idea of what you did, how It contrlbutes to the milestone, and what made the activity significant. Make a general statement about what was learned or found when an activity is identifled as completed.

In cases where one task funds work that is being contributed to by another task, the lead task is responstble for reporting all work in that area. Do not list work that all tasks took part in, such as planning or team meetings. List conferences, trips, subrnission of reports . and visitors only when an impact on the project is explained.

\section{Major Problem Areas or Changes and Action Taken}

Describe potential problems and describe actions to prevent their occurrence or minlmize their impact. Identify existing problems and corrective actions to get back on cost/ schedule. Describe decisions that have not been made that affect the progress of technical work. Describe what information you will pro. vide as a basis for making the decision or what other action you will take to make sure the decision will or can be made. Describe any changes in the approach or scope of work previously agreed upon in task plans. Problems discussed here, if they affect costs or schedule, should also be consistent with discussions under "Varlance,"

\section{Varlance}

This section is for identifying any cost or schedule variances. Include information about what the variance is (cost or schedule), what caused it, and how it will be corrected. Explain cumulative cost variances that are $15 \%$ or $\$ 25,000$ over or under the budgeted cumulative amount, whichever is smaller. Otherwise, the words "no significant cumulative varlance" should appear. In monthly report input to Project Office, explain monthly varlances and corrective actions.

Explain schedule variances that occur when your work deviates from the planned schedule.

\section{Planned Work for the Next Three Months}

Statement of work to be performed and milestones due in the next three months. 


\section{APPENDIX E}

CHANGE REgUEST RECORD AND CHANGE CONTROL LOG 


\section{Hanford Environmental Dose Reconstruction Project}

\section{CHANGE REQUEST RECORD}

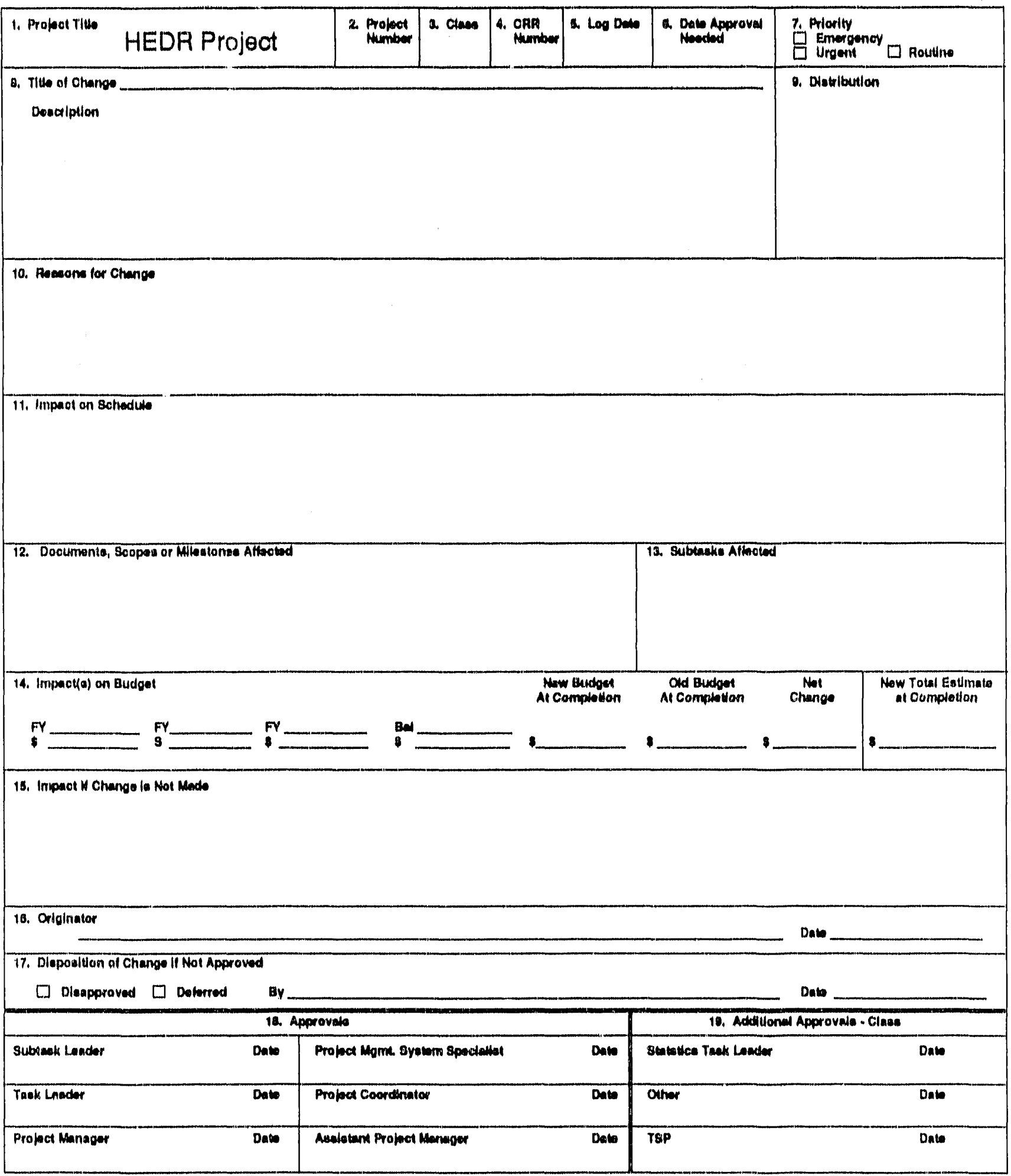

E.1 


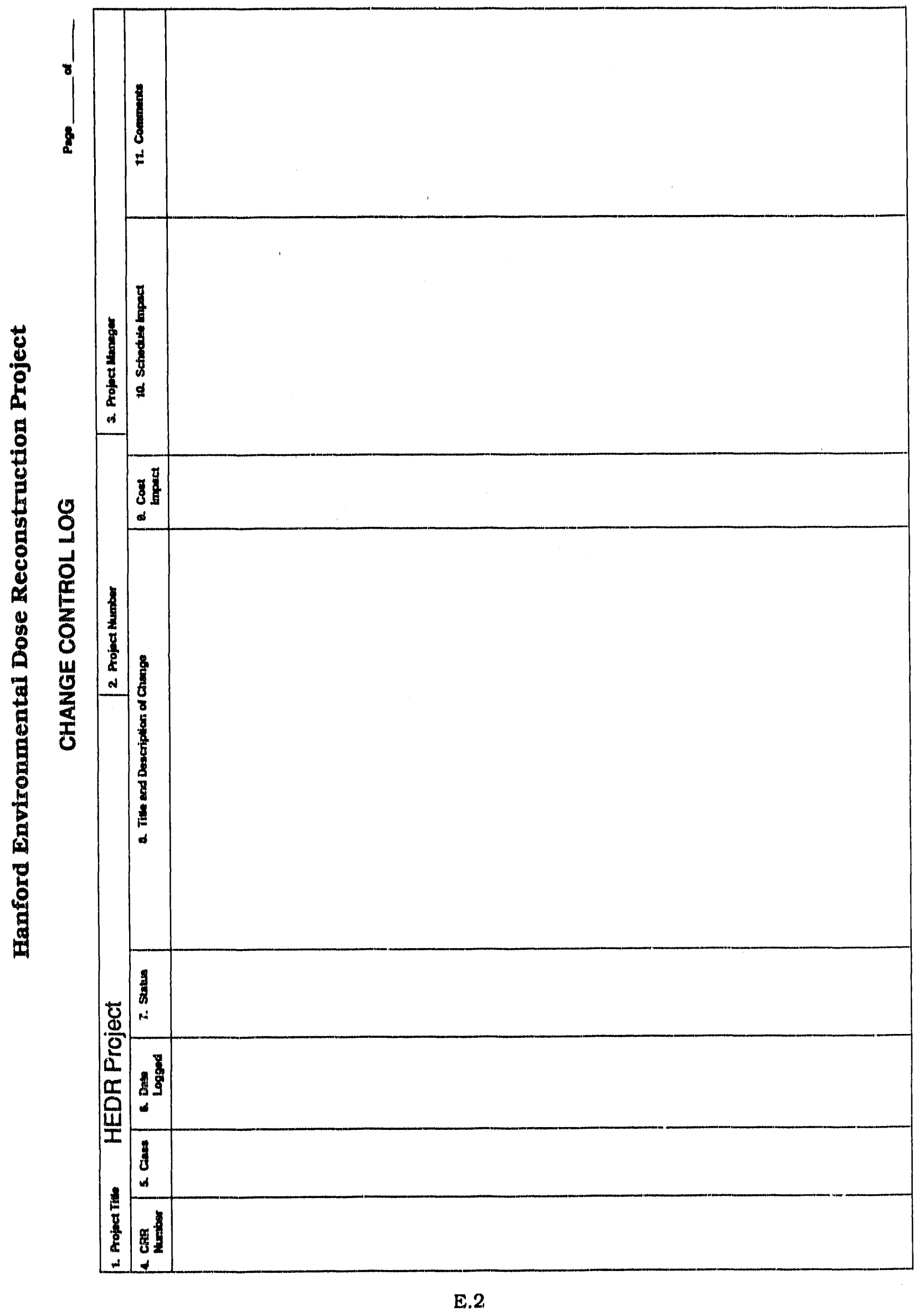




\section{APPENDIX F}

HEDR REPORT FORMAT 


\section{APPENDIX F}

\section{HEDR REPORT FORMAT}

THll Slgnature Page

Battelle Title Page

Acknowledgements (optional)

\section{Preface}

The preface contains remarks that are not directly part of the subject matter of the report, but which help the reader put the material in context or alert the reader to key issues.

Include these items in the preface:

- HEDR Project ol jectives.

Use a statement like this: The primary objective of the Hanford Environmental Dose Reconstruction (HEDR) Project is to develop estimates of the radiation doses that populations and individuals could have received form Hanford SIte operations since 1944, with descriptions of the uncertainties inherent in such estimates. A secondary objective is the make project documentation (project reports and referenced documents) avallable to the public. An independent Technical Steering Panel directs the project, which is conducted by Battelle staff from the Pacific Northwest Laboratory.

- Status of project/Previous related work/how this work fits in.

Describe decisions being supported

("Abstract - only needed if summary is more than two pages. Abstract is one page max. description of what the report contains, sort of a mini-summary.)

\section{Summary}

Try to keep to 2 pages. If more than 2 pages, add an abstract." The summary includes these elements:

Introduction

Scope of Work

Technical Approach

Results

Recommendations

Contents, including lists of tables and figures

1.0 Introduction

Background to Work Being Described

Purpose

Scope

Hanford factlities involved

Radionuclides/source terms

Time 'periods

Area/domain

Specific individuals

Special populations

Lifestyle/food Habits

Agricultural considerations

Environmental monitoring data

Pathways and dosimetry

Preview of report

2.0 Technical Approach

Data Requirements

Screening Calculations

Modeling and Computer codes

Sensitivity/Uncertainty Analysis

Statistical Analysis

3.0 QA and Data Quality Objectives Achievement

4.0 Results 
5.0 Conclusions

6.0 Recommendations for expansion or extension of work

Include results of decision analysis, if one was done.
7.0 References

Appendices

Distribution List (after TSP approval) 


\section{APPENDIX G}

\section{HEDR PROJECT ACTION TRACKING SYSTEM}




\section{HEDR Project ActionTracking System Input/Change Sheet}

Task \# Work Order \# QA Level

ATS \# Entry Date

Title

Action

Product for Delivery

Internal or Extemal Delivery

Assigned By

Date Assigned

Person Responsible Internal Due Date

Reviewer Date Due to Client

How Assigned Date Delivered

Document Reference File number

Cornments 


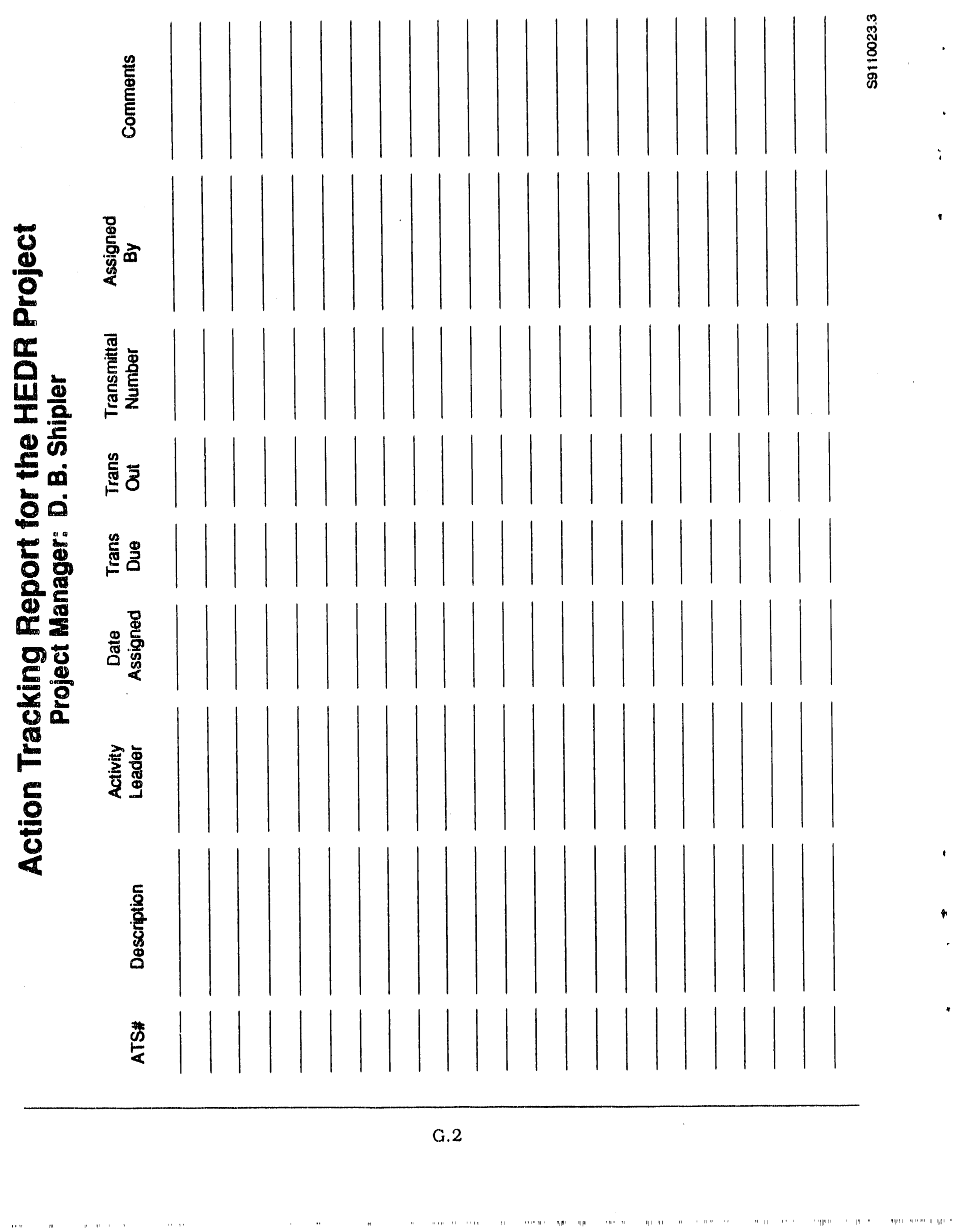




\section{DISTRIBUTION}

No. of

Coples

\section{OFFSITE}

18 Technical Steering Panel

- D. S. Barth

Untversity of Nevada

4505 Maryland Parkway

Las Vegas, NV 89154

- W. A. Bishop

2503 Wedgewood Court SE

Olympla, WA 98501

- M. L. Blazek

Oregon Department of Energy

625 Marion Street N.E.

Salem. OR 97310

- G. G. Caldwell

Director

Tulsa City-County Health Dept.

4616 East 15 th Street

Tulsa, OK 74112

- S. N. Davis

Dept. of Hydrology \& Water

Resources

Bldg. 11

University of Artzona

Tucson, AZ 85721

- N. J. Germond

224 Iron Mountain Blvd.

Lake Oswego, OR 97034

- P. C. Klingeman

Ctvil Engineering Dept.

Oregon State Untversity

Corvallis, OR 97331-2302

* K. J. Kopecky

Fred Hutchinson Center

Research Center

1124 Columbla Street

Seattle, WA 98104
No. of

Coples

- P. D. McGavran

Dept. of Health and Welfare 450 W. State St., 4th Floor

Bolse, ID 83720-5450

- R. L. Morrill

Dept. of Geography

Darthmouth College

Hanover, NH 03755

- A. H. Murphy

Department of Atmospheric Sciences

Oregon State Untversity

Corvallis, OR 97331-2209

- D. W. Price

Agricultural Economics

Hulbert Hall Room 211

Washington State Unlversity

Pullman. WA 99164-6210

- M. A. Robkin

Radiological Sciences SB-75

Untversity of Washington

Seattle, WA 98195

- G. S. Roessler

202 Nuclear Sciences Center Untversity of Florida

Gainsville, FL 32611

- B. Shleien

2421 Homestead Drive Stlver Springs, MD 20902

- A. P. Slickpoo, Sr. P.O. Box 331 809 Nez Perce Lane Kamiah, ID 83536

- J. E. TUll

Rt. 2 Box 122

Neeses, SC 29107

- D. E. Walker, Jr. c/o P. Arroyo 2041 Walnut St. Boulder, CO 80302 
No. of

Coples

Other

2 DOE Office of Sclentuffc and

Technical Information

Technical Information Center

P.O. Box 62

Oak RIdge, TN 37830

B. G. Brooks, EH-421

Department of Energy

Room J-112

Germantown, MD 20545

18 K. CharLee

Office of Nuclear Waste Mgmt.

Department of Ecology

99 South Sound Center

Mall Stop PV-11

Olympla, WA 98504

A. Fingeret, GC-22

Department of Energy

Forrestal Bldg. Room 6H.087

1000 Independence Ave.

Washington, DC 20585

K. Gebble, Secretary

Washington Dept. of Health

MS ET-21

Olympla. WA 98504

- W. A. Glass

13874 E. 47th Lane

Yuma, AZ 85365

D. B. Manders

Chronic Disease Epidemiology

Dept. of Health

MS EY-12

1408 State St.

Olympia, WA 98504

W. J. Roberds

Golder Associates

4104 148th N.E.

Redmond, WA 98052

- M. Sage

Centers for Disease Control

1600 Clifton Rd., Mall Stop F-28

Atlanta, GA 30333
No. of

Coples

- B. Smith

Centers for Disease Control

1600 Clifton Rd., Mall Stop F-28

Atlanta, GA 30333

J. Thomas

HEAL

1720 N. Ash

Spokane, WA 99205

\section{ONSITE}

7 DOE Richland Feld Office

- R. F. Brich. TSD

A5-55

M. W. TYernan, TSD

A.5.55

Public Reading Room (5)

A.1.65

56 Paciflc Northwest Laboratory

- D. L. Alamia

K3 -70

P7-64

K6-64

K6-77

K1-67

P7-75

P7-64

K1 -59

K6-89

KK6-13

K6-89

$\mathrm{K} 6-77$

K7-34

K6-80

K1-33

P8-55

K1-36

K6-42

K6-42

K1-60

K3-54

K6-55

HARC

K. 1-57

K6-86

K1-38

K3-54

K2-02

K7-15

K1-40

K6-03

KK6-64

K1-73

"Controlled copy 
No. of

Coples

P. K. Schuette

- D. B. Shipler

J. C. Simpson

J. W. Smith

P. S. Stansbury

- D. L. Stewart

- W. L. Templeton

"Controlled copy
No. of

Coples

K1-09

K.6-89

K7-34

P7-72

K3-53

K6-91

K1-30
К6-77

K6-05

H. E, Westerdahl

$\mathrm{K} 1-46$

W. R. Willey

K1.06

K3-70

Records Center

Technical Library (2) 


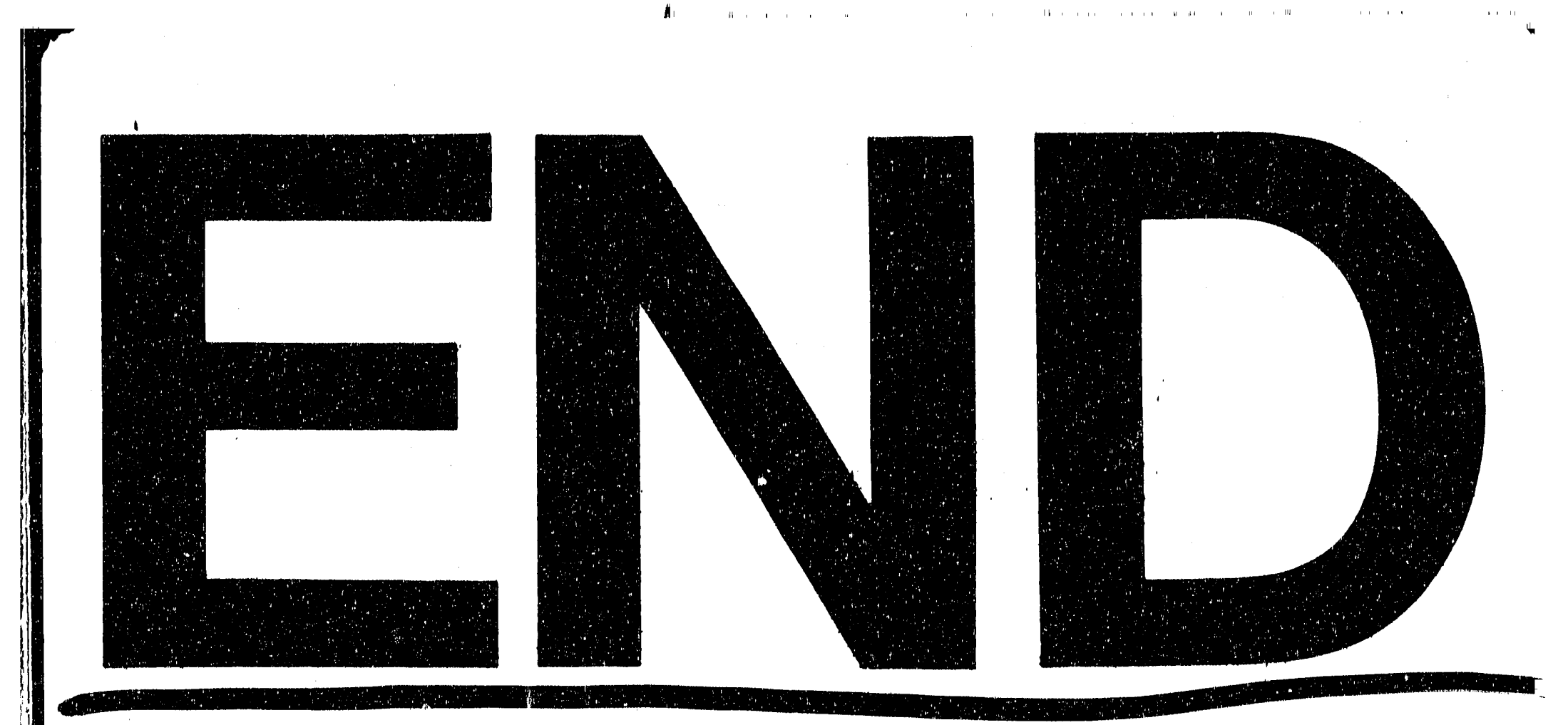


